\title{
Holocene climatic variations in the Western Cordillera of Colombia: a multiproxy high-resolution record unravels the dual influence of ENSO and ITCZ
}

\author{
Paula Muñoz ${ }^{\mathrm{a}, 1}$, Georges Gorin ${ }^{\mathrm{a},{ }^{*}}$, Norberto Parra ${ }^{\mathrm{b}}$, Cesar Velásquez ${ }^{\mathrm{b}}$, \\ Diego Lemus ${ }^{c}$, Carlos Monsalve-M. ${ }^{b}$, Marcela Jojoa ${ }^{b, 2}$ \\ a Department of Earth Sciences, Earth and Environmental Science Section, University of Geneva, rue des Maraîchers 13, \\ CH-1205 Geneva, Switzerland \\ ${ }^{\mathrm{b}}$ Facultad de Ciencias, Universidad Nacional de Colombia, sede Medellin, Calle 59A, no. 63-20, Medellin, Colombia \\ ${ }^{c}$ Facultad de Estadística, Universidad Santo Tomás, Carrera 9, no. 51-11, Bogotá, Colombia
}

* Corresponding author. Tel.: +41796811833

E-mail address: georges.gorin@unige.ch (G. Gorin)

${ }_{1}^{1}$ Present address: Chalice Court Flat 1, 41 Chevening Rd, SE19 3TD Upper Norwood, UK

${ }^{2}$ Present address: Universidad de Medellín, Carrera 87 № $30-65$, Medellín, Colombia. 


\section{Introduction}

2

Records of climate change are particularly important in the tropics, where major thermal energy interchanges take place between oceans and atmosphere. Climatic events like the migration of the Intertropical Convergence Zone (ITCZ, e.g., Haug et al., 2001; Haug et al., 2003; Peterson and Haug, 2006; Yancheva et al., 2007; Wanner et al., 2008) and the El Niño-Southern Oscillation (ENSO, e.g., Thompson, 2000; Moy et al, 2002; Riedinger et al., 2002, Flantua et al., 2016a) are typically associated with the tropics but influence the global climate. The here studied high-altitude site, the Páramo de Frontino at the northern termination of the Colombian Western Cordillera (Fig. 1), is ideally located because it is exposed to the climatic influence of both the Atlantic and Pacific oceans.

In the last 50 years, Colombia has been one of the best-studied tropical countries with respect to Quaternary climate change and associated variations in the distribution of vegetation (Flantua et al., 2015). Palynology has been the main tool for these investigations: Van der Hammen and González (1960a, b), González et al. (1965), Van der Hammen et al. (1973), Van Geel and Van der Hammen (1973), Van der Hammen et al. (1980/1981), Hooghiemstra (1984), Kuhry (1988), Mommersteeg (1998), Thouret et al. (1996), Wille et al. (2001), Van der Hammen and Hooghiemstra (2003), Groot et al. (2011), among others. The period since the last glacial maximum is the best covered by pollen-based records from a variety of biomes (páramo, montane forest, savana, rainforest, dry forest), which were used to unravel the dynamic history of these ecosystems (e.g., Marchant et al., 2001, 2002, 2006; Flantua et al., 2015). In montane areas, the Eastern Cordillera of Colombia is palaeoecologically best studied, whereas the history of ecosystems in the Western Cordillera (where the Páramo de Frontino is located) is poorly known. Nevertheless, information about the ecology and biotic diversity of montane forests and tropical alpine grasslands (called "páramos"), including those of the Western Cordillera, can be found in Cuatrecasas (1958), Rangel (1995), Gentry (1995), Rangel et al. (1997), Van der Hammen et al. (2005) and Rangel (2010), among others. 
High-resolution pollen records over the last 15,000 years, which can provide reliable proxies for climate variations, are rare in the South American tropics (Flantua et al., 2015; Flantua et al., 2016a; Flantua et al., 2016b; Urrego et al., 2016). Outside of Colombia, pollen records reflecting the Holocene have been well studied in Venezuela (Bradbury et al., 1981; Rull et al., 2005), Ecuador (Niemann et al., 2009; Brunschön and Behling, 2010), Peru (Weng et al., 2006) or Yucatan (Leyden, 2002). Although Colombia probably presents the largest number of palynological publications of all tropical countries (Flantua et al., 2015), very high-resolution studies (i.e., those with a time resolution of less than $50 \mathrm{yr}$ ) are noticeably rare (Flantua et al., 2016a, 2016b; Urrego et al, 2016): in Colombian lowlands, Wille et al. (2003) studied the last 11,000 years at Lake Las Margaritas (altitude of $290 \mathrm{~m}$ asl) with a time resolution of $50 \mathrm{yr}$. At high altitude, GonzálezCarranza et al. (2012) studied the Lake La Cocha record (altitude of $2780 \mathrm{~m}$ asl) spanning the last 14,000 years on the Amazonian flank of the Andes in southern Colombia with a ca. 25 yr resolution. Velásquez (2005) analyzed the last 4000 years in the Llano Grande (LLG) mire in the Páramo de Frontino (altitude of $3460 \mathrm{~m}$ asl) with a time resolution of $20 \mathrm{yr}$, making it the first palynological study of the late Holocene in Colombia at a near-decadal timescale. Muñoz (2013) further studied palynologically the same site at near-decadal time scale down to ca. 11,500 cal yr BP. Our study uses the synthetic palynological results of the latter two authors as a palaeoclimatic proxy. Other high-altitude sites have been studied by palynology in the subtropical Andes, spanning the Lateglacial and Holocene, e.g., in Ecuador (Hansen et al., 2003), Venezuela (Rull et al., 2005) or Peru (Weng et al., 2006), but their resolution is over $100 \mathrm{yr}$. Another aspect in continental records is the stratigraphic continuity: these intervals are often affected by significant hiatuses (Van 't Veer et al., 2000; Groot et al., 2013). A continuous stratigraphical sequence with reliable age dating (Flantua et al., 2016b) is a must for high resolution. Finally, palynological data must be supported by other proxies (Flantua et al., 2015), such as geochemistry, sedimentology or other organisms (diatoms, chironomids, etc.), e.g., Velez et al. (2001).

The high altitude and isolation of the Páramo de Frontino has preserved it from anthropogenic 54 influences. For this reason, its geomorphology, biophysical aspects and mire sediments have been studied for the past twenty years (Jaramillo and Parra, 1993; Lozano et al., 1999; Parra and 
Jaramillo, 1999; Parra et al., 2010a,b,c; Velásquez et al., 1999; Velásquez, 2005, among others). The first core in the LLG mire studied in this paper was taken in 1995 and showed that the sampled sediments presented a 17 kyr long record (Velásquez and Hooghiemstra, 2013).

In this paper we present results of a multiproxy research on palaeoclimatic variability carried out on the continuous sedimentary sequence cored at the centre of the high-mountain LLG mire in the Páramo de Frontino and spanning the last 11,500 years. This study combines data from pollen (biotic proxy) and X-ray microfluorescence ( $\mu \mathrm{XRF}$, abiotic proxy). The objectives are twofold: 1$)$ to reconstruct at a near-decadal timescale changes in the vegetation associations and inferred climate change (temperature and humidity) and compare the humidity record derived from local aquatic vegetation with the higher-resolution (sub-annual) $\mu \mathrm{XRF}$ rainfall proxy; 2 ) to attempt to infer the mechanisms that have driven the observed climatic variations at local and interregional scales, We compare our new data with selected high-altitude north Andean sites and a Caribbean marine site, with particular emphasis on potential connections between tropical Pacific and Atlantic climates.

\section{Environmental and geological setting}

\subsection{Geomorphological and geological setting}

The Páramo de Frontino is located at $6^{\circ} 29^{\prime} \mathrm{N}$ and $76^{\circ} 06^{\prime} \mathrm{W}$ (Fig. 1). It lies in the Department of Antioquia, some $100 \mathrm{~km}$ to the northwest of the city of Medellin and approximately halfway between the Pacific and Atlantic oceans. It forms the largest tropical montane grassland area in the Western Cordillera and contains several wetlands. The Páramo de Frontino corresponds geomorphologically to a large cone truncated at an altitude of ca. $3600 \mathrm{~m}$ asl. This high plateau is crossed by a W-E trending ridge culminating at $4080 \mathrm{~m}$ asl. The steep environmental gradients and short spatial 
Geologically, the Páramo de Frontino consists of a Tertiary dioritic to monzonitic pluton, which penetrates Cretaceous turbidites and contains volcanic rocks (basalts, andesites and tufs) also of Tertiary age (Parra et al., 2010a). The páramo flanks present steep slopes cut by deep canyons. The flat zone at the top exhibits various glacial landforms including depressions that drain eastwards (Fig. 2A). The latter were infilled by sediments during Lateglacial and Holocene times. They appear today as mires/peat bogs flooded during the wet season. The largest one studied here is the LLG mire, which lies at $3460 \mathrm{~m}$ asl (Fig. 2B). The area of LLG is of some $0.2 \mathrm{~km}^{2}$ and stratigraphically continuous sediments are over $12 \mathrm{~m}$ thick in the central part of the basin (Fig. 2C). This study is based on cores LLG-2 and LLG-5 recovered at the depocentre. The study of Velásquez and Hooghiemstra (2013) is based on core LLG-1 taken on the flank of this basin (Fig. 2C), where the total sedimentary sequence is reduced and presents stratigraphical hiatuses.

93

94

\subsection{Present-day climate}

Modern climatic conditions in the Páramo de Frontino are still being poorly studied. There are no weather stations in the páramo and data come either from spot observations or from weather stations located at lower altitude and several kilometers distance (Monsalve, 2005). The climate has a typical high-altitude tropical character. It has an important diurnal range, whereas the mean monthly and mean annual temperatures (MAT) vary little. Espinal (1992) quotes MAT between 6 and $12{ }^{\circ} \mathrm{C}$, whereas Rangel and Aguilar (1995) mention a maximum temperature of $10.5^{\circ} \mathrm{C}$, a minimum temperature of $-1.9^{\circ} \mathrm{C}$ and a MAT of $4.6^{\circ} \mathrm{C}$. The best estimate of MAT in LLG can be derived from stabilized soil temperatures in the Páramo de Frontino measured between 3100 and $3600 \mathrm{~m}$ asl (Velásquez, 2005). A value of $8.6^{\circ} \mathrm{C}$ at $3460 \mathrm{~m}$ asl will be used as present-day MAT for the LLG location studied.

Precipitation change in Colombia is driven by the position of the ITCZ (see Fig. 1) combined with the moisture brought by the low-level Choco jet (Poveda and Mesa, 2000) in the Pacific. At annual scale, according to the data of the weather stations close to the Páramo de Frontino 
110 (Monsalve, 2015), the months of January and February are the driest of the year (southern

111 position of the ITCZ). The second dry period lasts from June to July, with August to September

112 slightly rainier (northern position of the ITCZ). Highest rainfall occurs usually in April, May and

113 October, coinciding with the northward/southward progression of the ITCZ over the study area.

114 Because the Western Cordillera partially acts as a rain shadow, its western flank receives more

115 precipitation than its eastern flank. This annual distribution of precipitation is further affected by

116 ENSO, marked by the Niño and Niña phenomena with a time scale of two to seven years. ENSO

117 is the main forcing mechanism of Colombia's hydro-climatology at interannual timescales

118 (Waylen and Poveda, 2002; Vuille and Garreaud, 2012; Flantua et al, 2016a). Overall, during El

119 Niño events, Colombia experiences a lack of rain, and increased air temperature leads to higher

120 evaporation. The reverse is generally valid during La Niña phases. The impact of ENSO occurs

121 earlier and is stronger in western and central Colombia than in the east (Poveda et al., 2001).

122 From the data of weather stations, mean annual precipitation between 2000 and 3000

$123 \mathrm{~mm} /$ year can be assumed for the study area. Finally, the high altitude, and low atmospheric

124 pressure (less water vapour) as a consequence, make the atmosphere in the study area 125 permeable to solar radiation.

2.3. Modern vegetation

The general altitudinal distribution of vegetation in the northern Andes has been studied by

131 Van der Hammen and González (1960a; 1960b and 1963), Van der Hammen (1974), Van der 132 Hammen et al. (1980), Cleef (1981), Rangel et al. (1982), among others. The altitudinal range of 133 the main vegetation associations may slightly differ between the dry and wet sides of the 134 mountains, between the Eastern and Western cordilleras, and between northern, central (Cleef 135 and Hooghiemstra, 1984) and southern Colombia (Wille et al., 2001). The páramo vegetation in 136 the Western Cordillera has been investigated by Rangel et al. (1999) and Cleef et al. (2005). In 
137 the Páramo de Frontino, this type of vegetation has been studied by Espinal et al. (1983), 138 Sánchez (1998) and Rangel et al. (1999).

139 Many taxa show similar altitudinal ranges and justify the recognition of general vegetation

140 zones (or vegetation belts), characterized by suites of co-occurring taxa (Table 1) forming 141 identifiable plant associations (Bogotá-Angel, 2011). The vertical distribution of main plant 142 associations in the Páramo de Frontino (Fig. 3A) follows that of Velásquez (2005) and Velásquez 143 and Hooghiemstra (2013).

144 Ecotones are determined by environmental factors more or less well identified (Hooghiemstra 145 et al., 2012). The transition from sub-Andean forest (or lower montane forest, Groot et al., 2011) 146 to Andean forest (or upper montane forest, Groot et al., 2011) is mainly governed by the 147 occurrence of night frost, which occurs mainly during dry periods (Wille et al., 2001). The 148 transition from upper montane forest to subpáramo corresponds to the upper forest line (UFL, 149 Fig. 3A), i.e., to the uppermost contour of closed forest (Bakker et al., 2008). Its altitudinal 150 position is mainly governed by MAT, although changing atmospheric $\mathrm{pCO}_{2}$ also plays a still 151 unquantified role (Boom et al., 2002; Groot et al., 2011; Hooghiemstra et al., 2012; Groot et al., 152 2013). The factors driving the transition from shrubby subpáramo to herbaceous páramo are little 153 known, but frost frequency and humidity probably play an important role (Hooghiemstra et al., 154 2012; Torres et al., 2013).

\section{Material and methods}

\subsection{Coring and sampling}

161 Nine cores have been taken in the LLG Basin (Fig. 2C). Following the acquisition in 1995 of 162 core LLG-1 (Velásquez and Hooghiemstra, 2013), a depth survey of the basin was carried out. 163 Subsequently, cores LLG-2 to LLG-9 acquired between 1999 and 2010 have been positioned 164 closer to the centre of the basin and penetrated a much thicker section. Cores LLG-2 to LLG-9 
165 have been recovered using a hand-operated "Russian" corer. It cuts 50-cm long half-cylindrical 166 cores with a diameter of $5 \mathrm{~cm}$. This device has the great advantage of not compacting sediments, 167 because once set in the subsurface at the desired depth it cuts off the sediments horizontally. 168 Cores LLG-6 to LLG-9 (Fig. 2C) have been recovered twice, the twin cores being separated by 169 less than $50 \mathrm{~cm}$. The twin cores LLG-9 have been vertically displaced of $25 \mathrm{~cm}$ to insure a full 170 continuity of the sediments.

171 Cores LLG-2, $-5,-7,-8$ and -9 have reached glacial clays or bedrock below a thick organic172 rich sequence. All cores have been photographed in the field. Cores LLG-2 to -4 have been 173 studied in detail in the field, particularly core LLG-2 (Parra et al., 2010c), and sampled at $1 \mathrm{~cm}$ 174 increments for palynological studies. Cores LLG-5 to -9 have been packed in plastic half tubes 175 and carried to the National University of Colombia in Medellin for further studies. Core LLG-5 has 176 been further sampled using U-channels and subsequently studied at the University of Geneva 177 (Switzerland) both for $\mu \mathrm{XRF}$ and lithology.

178 The present research is based on cores LLG-2 for palynology and LLG-5 for geochemistry. 179 Samples used for ${ }^{14} \mathrm{C}$ analyses come from cores LLG-2, $-3,-4,-5$ and -8 in the central part of the 180 basin.

\subsection{Palynology}

\subsubsection{Processing, counting and result display} Palynological data used in this study (Velásquez, 2005; Muñoz, 2013) all come from core

188 LLG-2 (Fig. 2C). All samples have been prepared at the Palaeoecology Laboratory of the 189 National University of Colombia (Medellin). Velásquez (2005) has studied the upper $220 \mathrm{~cm}$ of 190 the core with samples taken at $1 \mathrm{~cm}$ increments. Muñoz (2013) has studied the same core from $191220 \mathrm{~cm}$ down to $754 \mathrm{~cm}$ with samples taken at 2 to $3 \mathrm{~cm}$ increments. 
Sediment samples of $1 \mathrm{~cm}^{3}$ have been treated with standard pollen preparation procedures

193 including potassium hydroxide and acetolysis (Faegri and Iversen, 1989). One tablet of exotic 194 Lycopodium spores has been added to each sample for calculation of the pollen concentration 195 values. Pollen samples have been mounted in glycerin gelatin, and slides sealed with wax. Pollen grains from the regional vegetation have been included in the pollen sum and ecologically 197 grouped according to the different vegetation zones (Table 1, Fig. 3A). Pollen from aquatics and 198 undetermined pollen grains, algal colonies and fern and fungal spores have been excluded from 199 the pollen sum. In the Páramo de Frontino, local vegetation consists essentially of aquatic plants, 200 for which an environmental model has been established by Parra et al. (2010b) (Table 1, Fig. 201 3B). For the pollen sum, a minimum of 300 pollen grains has been counted by Velásquez (2005) 202 for the interval of $0-220 \mathrm{~cm}$ in core LLG-2, whereas Muñoz (2013) has counted all pollen and 203 spores in $21 \mu \mathrm{ml}$ of pollen solution for the interval 220-754 in the same core. In both studies, 204 pollen and spore assemblages are comparable and the relative proportions of taxa can be 205 compared and merged into one single composite pollen record covering the interval 0-754 $\mathrm{cm}$. 206 For pollen and spore identification, Velásquez (2005) and Muñoz (2013) have used 207 Hooghiemstra (1984), Kuhry (1988), Roubik and Moreno (1991), Salomons (1986) and 208 Velásquez (1999), as well as the reference collections at the Palaeoecology Laboratory of the 209 National University of Colombia in Medellín and at the Institute for Biodiversity and Ecosystem 210 Dynamics (IBED) of the University of Amsterdam (Netherlands).

211 Percentage calculations and data plotting have been carried out using the software TILIA and 212 TILIAGRAPH (version 2.0.2, Grimm, 1987).

\subsubsection{Use of pollen data as palaeoenvironmental and climatic proxy}

Van der Hammen and González (1960a, 1960b and 1963) defined the UFL as the uppermost 218 and mainly continuous boundary between the about $5 \mathrm{~m}$ high or taller forest vegetation and the 219 dwarf forest belt (subpáramo). Isolated forest patches, small dwarf forest at higher altitudes in 
220 wind-protected valleys should not be taken into account. The concept of shifting UFL has been 221 widely applied to reconstruct palaeotemperatures (e.g., Hooghiemstra, 1984 and 1989; 222 Hooghiemstra and Ran, 1994; Mommersteeg, 1998; Van 't Veer and Hooghiemstra, 2000; Wille 223 et al., 2001; Torres, 2005; Bogotá-Angel, 2011; Groot et al., 2011, Hooghiemstra et al., 2012).

224 The percentage of arboreal pollen (AP\%) reflects the altitudinal position of the UFL, each $5 \%$ 225 change in AP\% corresponding to a $100 \mathrm{~m}$ shift of the UFL (Hooghiemstra, 1984; Van ' $t$ Veer and 226 Hooghiemstra, 2000; Bakker et al., 2008; Groot et al., 2011; Velásquez and Hooghiemstra, 2013; 227 Groot et al., 2013). As mentioned before, the position of the UFL is largely determined by the 228 MAT (Groot et al., 2011; Groot et al., 2013). Because there are no studies in the Western 229 Cordillera about lapse rates, a lapse rate of $0.6^{\circ} \mathrm{C} / 100 \mathrm{~m}$ forest displacement has been chosen 230 for the study site (Velásquez and Hooghiemstra, 2013). The present-day UFL in the Páramo de 231 Frontino can be estimated at $3450 \mathrm{~m}$ asl (Rangel et al., 1999; Velásquez, 2005). The 232 palynological data of Velásquez (2005) in LLG show that the present-day AP\% is ca. 53\% at $2333460 \mathrm{~m}$ asl at the study site. We have used the present-day stabilized soil temperature of $8.6^{\circ} \mathrm{C}$ 234 (Velásquez, 2005) as the best estimate of MAT at the elevation of the mire (3460 m asl). Using 235 these parameters and the AP\%, we have estimated the elevation of the UFL and the MAT with 236 the following relations (1) and (2):

$$
\begin{gathered}
\mathrm{UFL}=3450+\left[\frac{(\mathrm{AP} \%-53)}{5}\right] \times 100 \\
\mathrm{MAT}=8.6+\left[\frac{(\mathrm{UFL}-3450)}{100}\right] \times 0.6
\end{gathered}
$$

237 Where:

$238 \mathrm{UFL}=$ upper forest line in meters; $3450=$ present-day altitude $(\mathrm{m}$ asl) of UFL; value of $53=$ 239 present-day AP\% at $3460 \mathrm{~m}$ asl (elevation of study area); values of 5 and $100=$ each $5 \%$ 240 change in AP\% corresponds to an UFL shift of $100 \mathrm{~m}$; MAT = mean annual temperature $\left({ }^{\circ} \mathrm{C}\right)$ 241 at mire elevation; $8.6=$ present-day MAT $\left({ }^{\circ} \mathrm{C}\right)$ in the study area; value of 0.6 = lapse rate of $242 \quad 0.6^{\circ} \mathrm{C} / 100 \mathrm{~m}$ forest displacement. 
Velásquez and Hooghiemstra (2013) have used slightly different values of present-day MAT $\left(9.5^{\circ} \mathrm{C}\right)$ and AP\% (40\%), but these differences do not affect significantly the relative changes in UFL and MAT over time.

247 Varying proportions of local aquatic vegetation are indicative of changing water levels in the mire and can be used as a proxy for rainfall (e.g., Hooghiemstra, 1984 and 1989; Van 't Veer and 249 Hooghiemstra, 2000; Torres et al., 2005; Bogotá-Angel, 2011; Van Boxel et al., 2014; Urrego et al., 2016). In LLG the local aquatic vegetation includes deep water plants, marsh and cushion vegetation (Table 1). The ecology of the modern aquatic and marsh vegetation in the Páramo de 252 Frontino has been studied by Parra et al. (2010b). This model can be applied to estimate the 253 water depth of the LLG lake (Fig. 3B), using relation (3):

$$
\text { Water Depth }=\frac{(\% \text { Isoetes } \times 60)+(\% \text { Cyperaceae } \times 10)+(\% \text { Plantago } \times 0.1)}{100}
$$

254

255

256

Where:

Water depth $=$ estimated water depth of the mire $(\mathrm{cm})$; values of 60,10 and $0.1=$ average water depth in $\mathrm{cm}$ corresponding to respective taxa according to the model of figure $3 \mathrm{~B}$ (in the marsh vegetation, only the Cyperaceae have been used because they are dominant).

\section{3. $X$-ray fluorescence $(X R F)$}

Recognizing chemical elements in lake sediments may provide significant climate and environmental information. In this respect, Jansen et al. (1998) have developed a non-destructive logging technique applying XRF for the determination of major-element concentrations in split sediment cores. Because of the high resolution of its semi-quantitative records, XRF is a useful tool for detailed time-series analysis ( e.g., Jansen et al., 1998; Röhl and Abrams, 2000; Helmke et al., 2005). The principal advantage of this technique is the acquisition of high-resolution semicontinuous measurements, which can be carried out rapidly in a non-destructive way. 
Elemental analysis has been performed on the LLG-5 core using the EDAX Eagle III XPL

$270 \mu$ Probe at the Earth Science Department of the University of Geneva. Because of the extremely

271 high resolution of this instrument ( $\mu$ Probe), the high-density data acquired will be referred to as X-

272 ray microfluorescence $(\mu \mathrm{XRF})$ data. This allows the distinction from standard XRF data acquired

273 with lower resolution devices. Material for $\mu \mathrm{XRF}$ analyses has been sampled at the National

274 University of Colombia in Medellín in $50 \mathrm{~cm}$-long U-channels from the cores recovered with the

275 Russian corer (see above) and transported to the University of Geneva. The U-channels have

276 been cut into $10 \mathrm{~cm}$ long sections to be analyzed in the Eagle III spectrometre. Some 180 to 200

277 points have been measured for each $10 \mathrm{~cm}$ segment of the LLG-5 core down to a depth of $14 \mathrm{~m}$.

278 Only the results that are time-equivalent to the interval covered by the palynological data in core

279 LLG-2 (i.e., 0-754 cm) are presented here. Parameters used for measurements have been set at $28040 \mathrm{kV}, 450 \mu \mathrm{A}, 50 / 55 \mathrm{Dtm}$ at atmospheric pressure. Two profiles over the same sections have 281 been acquired in various parts of the core, giving consistent results. Measured values are 282 expressed in counts per second (cps). According to the manufacturer, the lowest level of 283 reliability is at around 7cps.

284 The elements present in the mineral fraction of sediments come essentially from running 285 waters in the catchment area of the LLG lake, where the bedrock is made principally of volcanic rocks (andesites, basalts and volcanic tufs). An ultra-high resolution record for $\mathrm{Fe}$ and $\mathrm{Ti}$ has been obtained. $\mathrm{Ti}$ is a very conservative element and should be preferred as a proxy for rainfall in 288 the catchment area (e.g., Haug et al., 2001; Peterson and Haug, 2006). Although less 289 conservative, Fe can also be used if not affected by diagenesis (Petersen et al., 2000). This is the 290 case in our study, where the Fe curve is fairly similar to that of Ti and will be used in the upper 291 part of the late Holocene where Ti measurements are less reliable because of their low values. 
The main aim of wavelet analysis (e.g., Weng and Lau, 1994; Torrence and Compo, 1998) is

297 to determine the frequency content of a signal and to assess the temporal variation of the

298 frequency content. The wavelet transform allows for tracking the time evolution of processes at 299 different scales in the signal. It has been used extensively in geosciences, e.g., to analyze 300 meteorological data, ocean and land temperatures, precipitation data, influence of ENSO on 301 tropical river discharge, etc... (Labat, 2005). In this study, wavelet analysis has been carried out 302 on $\mathrm{Ti}$ and Fe data to obtain time series and try to identify significant periods (amount of time for a 303 cyclic phenomenon to repeat itself) during the Holocene. It has been used to evaluate the time 304 series of red colour intensity for statistically significant variance. This method has been chosen 305 because of its use on non-stationary signals. By employing the adequate wavelet, it can provide 306 excellent time and frequency localization. Wavelet spectra have been calculated over the last 30712,000 cal yr BP (ca. 19,000 measurements) of the red colour intensity time series using a 308 continuous wavelet transform with significance testing. The chosen continuous Morlet wavelet 309 (Farge, 1992; Yi and Shu, 2012) has been used to calculate the wavelet power spectra and to 310 identify changes in variance within selected frequency time bands trough time.

311 The desktop operating system used is UBUNTU 11.10, which is based on the Debian Linux 312 distribution and is shared as free and open source software, using its own desktop environment. 313 The statistical software used is the open source R language (version 2.14; Fox and Andersen, 314 2005). Finally, the program PAST has been used to generate the Morlet wavelet and wavelet 315 power spectrum. This program is designed as a follow-up to PALSTAT, an extensive package 316 written by Ryan et al. (1995). It includes a number of functions commonly used in palaeontology 317 and palaeoecology.

\section{Results}


$324 \quad$ Lithological studies have been carried out on core LLG-2 by Parra et al. (2010c) and on core 325 LLG-5 in relation with the $\mu$ XRF study. The other cores have been studied to establish a precise 326 lithological correlation (Fig. 4). Although this study covers only the upper part of cores LLG-2 and $327-5$ (down to just below the limit between lithological units 2 and 3, Fig. 4), it is important to present 328 here the lithology of the whole stratigraphical section, which has been used to establish the age 329 model of the Lateglacial and Holocene infill.

330 Three lithological units are distinguished in the LLG basin. The lowermost Unit 1 (Fig. 4) 331 consists of light grey-white mineral mud with some dark laminae in the upper part. In core LLG-5, 332 the basal part contains coarse grains of plagioclases indicating the proximity of the basin 333 bedrock. The limit between units 1 and 2 is marked by an unconformity.

$334 \quad$ Unit 2 is made of dark brown organo-mineral mud. Its lower part is rich in diatoms (Fig. 4) and 335 contains at its base several tephra levels. The upper part of Unit 2 has a similar lithology, but is 336 poor in diatoms (Fig. 4). The top of the organo-mineral Unit 2 is another important marker for the 337 correlation of cores. It marks a sudden transition to sediments made essentially of vegetal 338 filaments and fragments with little mineral content apart from diatoms. This change occurs at 8.5 $339 \mathrm{~m}$ in LLG-5 and $7.43 \mathrm{~m}$ in LLG-2. Although this transition is rapid, there is no indication in any of 340 the cores of an unconformity at this level. The stratification remains horizontal and there are no 341 indications of a major hiatus. The difference in depth between LLG-2 and LLG-5 reflects a 342 microtopography in the basin and/or could be explained by differential compaction of underlying 343 sediments. The two cores are ca. $11 \mathrm{~m}$ apart.

$344 \quad$ Unit 3 is made of dark brown peat and organic mud very rich in vegetal filaments and 345 fragments. Its lower part is extremely rich in diatoms (Fig. 4), which can locally make up to $90 \%$ 346 of the sediments. These diatomites have a lighter brown colour. The upper part of Unit 3, i.e., the 347 uppermost six metres or so of all cores (except LLG-1) present an identical lithology made of 348 diatom-poor peat and organic mud (Fig. 4). Within this interval, the only marker is a few 349 centimetres thick intercalation of volcanic ashes situated at a depth of around $4 \mathrm{~m}$. 
Lines $a$ to $e$ in figure 4 correlate the main lithological changes observed in the sedimentary sequence. In the central part of the basin, where the sequence is complete and cores LLG-2 to LLG-9 close to each other, these lines correspond to isochrons. Correlation with core LLG-1 studied by Velásquez and Hooghiemstra (2013) must be considered with caution. This first core

354 was acquired on the flank of the basin (Fig. 3B) and its total thickness is about half of that 355 encountered at the centre of the depression. It corresponds to a condensed section and is likely 356 to present hiatuses. Moreover, it has been cored with a Dachnovsky sampler that compacts 357 sediments. Consequently, it is difficult to correlate with the type section consisting of LLG-2 and 3585.

\subsection{Age model}

The age model (Fig. 5) is based on 30 Accelerator Mass Spectrometry (AMS) ${ }^{14} \mathrm{C}$ 364 measurements carried out on samples recovered in the central part of the basin (Table 2). Those 365 carried out at the Poznan Laboratory in Poland (13 samples) have been calibrated using the 366 program CALIB 5.0 (two-sigma calibration values). This program was updated from CALIB 3.0 367 (Stuiver and Reimer, 1993) and CALIB 4.0 to use the INTCAL04 data set (Reimer et al., 2004). 368 The other 17 AMS datings have been performed at the Beta-Analytic Laboratory in Florida, which 369 provides both conventional radiocarbon and two-sigma calibrated ages. The latter calibration 370 uses the INTCAL04 database and the mathematics of Talma and Vogel (1993). Datings in core 371 LLG-2 have been obtained in an earlier research (Parra, 2005; Velásquez, 2005), and those in 372 cores LLG3, $-4,-5$ and -8 in the framework of the present study.

373 Two third grade polynomial functions have been used to accommodate the very low 374 sedimentation rate of the upper $150 \mathrm{~cm}$ of the cores. In this upper part, datings from LLG-2 375 complemented by those of LLG-5 give a very accurate function (Fig. 5). Another function has 376 been obtained using data from 150 to $1270 \mathrm{~cm}$. These two functions merge perfectly at $148 \mathrm{~cm}$ 377 and form the continuous depth vs. age curve shown in figure 5 . This curve gives an accurate age 
model to convert from depth to age both $\mu$ XRF data in core LLG-5 and palynological data in core

379 LLG-2 down to isochron $a$ at $405 \mathrm{~cm}$ (Fig. 4). Below isochron a down to a depth of about $9 \mathrm{~m}$, the 380 age vs. depth curve is based only on datings from LLG-5 (Fig. 4, Table 2). Below 9 m down to 381 isochron e (Fig. 4), the curve is also based on datings from LLG-3, -4, and -8 (Table 2), but the 382 correlation shows that there are little thickness variations between these cores and LLG-5 in this 383 interval. Therefore, between isochrons $a$ and $e$ (Figs. 4 and 5), the age model is directly 384 applicable to convert $\mu$ XRF levels from depth to age in core LLG-5. As for the depth to age 385 conversion of palynological data in core LLG-2 between isochrons $a$ and $e$, some adjustments to 386 the LLG-5 age curve are needed, particularly at the level of isochron $c$ where there is about one 387 metre depth difference between cores LLG-5 and LLG-2 (Fig. 4). This adjustment is made using 388 linear functions between isochrons $a$ and $e$, thereby providing a depth vs. age curve that can be 389 specifically applied to the LLG-2 palynological data below $405 \mathrm{~cm}$ (Suppl. Fig. 1).

390 The age model (Fig. 5) shows that the sedimentary section from isochron $e$ to the surface 391 represents a continuous record spanning the last 17,000 years, i.e., the Lateglacial and Holocene 392 periods. In this study, the top of the Younger Dryas equivalent (YD)/base Holocene has been 393 chosen at the level of isochron $c$ (dated at about 11,410 cal yr BP) for the following reasons (Van 394 't Veer et al., 2000): (1) isochron $c$ corresponds to a major lithological change from an organo395 mineral mud (characterizing the Lateglacial deglaciation phase) to an organic sediment rich in 396 vegetal filaments and fragments; (2) it corresponds to a major climatic change (see sections 4.3 397 and 4.4) both in temperature and humidity; (3) this limit falls within the YD chronozone.

398 The present study covers the topmost part of the Lateglacial, i.e., the YD from an age of 399 about 11,490 cal yr BP, and the whole Holocene period (Fig. 5). The oldest palynological sample 400 studied is at a depth of $754 \mathrm{~cm}$ in core LLG-2, which corresponds to a depth of $857 \mathrm{~cm}$ in core 401 LLG-5 where $\mu$ XRF analyses have been carried out (Suppl. Fig. 1).

402 Sedimentation rates in the Lateglacial and most of the Holocene vary between 75 and 90 $403 \mathrm{~cm} / 1000 \mathrm{yr}$ (Fig. 5). Sedimentation is reduced down to $40 \mathrm{~cm} / 1000 \mathrm{yr}$ during the last 3500 years, 404 corresponding essentially to peat formation. 


\subsection{Pollen analysis}

408

In our study we use the high-resolution palynological studies carried out at the centre of the basin in core LLG-2 by Velásquez (2005) and Muñoz (2013). Velásquez (2005) studied one

411 sample every centimetre between 0 and $220 \mathrm{~cm}$ and Muñoz (2013) one sample every 2 to $3 \mathrm{~cm}$ 412 between 220 and $754 \mathrm{~cm}$. Using the age model of core LLG-2 (Suppl. Fig. 1), the time resolution 413 of the palynological data can be estimated at ca. $25 \mathrm{yr}$ for the interval 0-3500 cal yr BP, ca. $10 \mathrm{yr}$ 414 for the interval $3500-4300 \mathrm{cal} y r$ BP and ca. $35 \mathrm{yr}$ for the interval $4300-11,490 \mathrm{cal} \mathrm{yr}$ BP.

Palynological results of Velásquez (2005) and Muñoz (2013) for the regional vegetation and the aquatics are presented in Fig. 6 (first and third diagram from the left). In the percentage diagram, the UFL corresponds to the transition from upper montane forest to subpáramo

418 vegetation. Using the AP\% curve, we have calculated altitudinal shifts of the UFL using relation 419 (1) described above (Fig. 6, second diagram from the left). From the altitude of the UFL and using 420 relation (2) we have also estimated the MAT for the past at the mire elevation. From the diagram 421 of the aquatics and using relation (3), we have estimated the mire water depth variation for the 422 past (Fig. 6, fourth diagram from the left). Using the percentage diagram, we have visually subdivided the record in seven intervals, the limits of which correspond to significant changes in

424 the altitudinal distribution of montane forest and páramo vegetation (Fig. 6).

Interval 1 represents the uppermost part of the YD (equivalent to the Colombian El Abra 426 stadial, Van der Hammen and Hooghiemstra, 1995; Van 't Veer et al., 2000). Palynological 427 proxies point to a cold and wet climate with a MAT some $3.5^{\circ} \mathrm{C}$ and an UFL about $600 \mathrm{~m}$ below 428 the present-day levels. The transition from YD to Holocene at about 11,410 cal yr BP is marked 429 by the sharpest increase in AP\% of the whole record. The MAT may have increased by some $4303.5^{\circ} \mathrm{C}$ and the UFL by some $600 \mathrm{~m}$ up to a level similar to the present-day one at $3450 \mathrm{~m}$ asl. A 431 sharp transition is also observed in the local aquatic vegetation pointing to a rapid decrease in the 432 water depth of the mire (Fig. 6). During interval 2, the UFL altitudinal level remained high until 433 about 10,700 cal yr BP, accompanied by dry conditions. During the following 1000 years until 
434 about 9700 cal yr BP (interval 3), the UFL went down by about $350 \mathrm{~m}$ which corresponds to a

435 drop in MAT of some $2-2.5^{\circ} \mathrm{C}$. The water level in the mire remained very low. Interval 4 (9700-

$4366900 \mathrm{cal}$ yr BP) is marked by an overall elevation of the UFL and MAT close to present-day

437 values. A slightly colder phase occurred between ca. 8100 and 7500 cal yr BP with a peak of 438 dryness in the upper part leading to the desiccation of the lake. Interval 5 (6900-4000 cal yr BP)

439 is marked by an overall decrease in the elevation of the UFL down to about $3000 \mathrm{~m}$ and in the 440 MAT down to about $2.5^{\circ} \mathrm{C}$ below the present-day value. This decrease in temperature is 441 accompanied by an increase in water depth of the mire culminating between 5000 and 4000 cal 442 yr BP. During interval $6(4000-2400$ cal yr BP) the UFL reached its highest altitude of the record 443 (Fig. 6). Two warm pulses can be recognized: a short one at the base of the interval (4000-3800 444 cal yr BP) is accompanied by drier conditions; a longer (3500-2600 cal yr BP) and warmer one, 445 during which the UFL may have gone up to $3900-4000 \mathrm{~m}$, which indicates a MAT up to $3^{\circ} \mathrm{C}$ 446 higher than today. This second warm spell was accompanied by very dry conditions that probably 447 led to the dessiccation of the lake. These two warm periods are separated by a cold and wet 448 interval (3800-3500 cal yr BP), during which the water depth of the lake increased to a level 449 similar to that in the upper part of interval 5 (Fig. 6). Interval 7 covers the last 2400 cal yr BP. It 450 shows a sudden drop in altitude of the UFL at around the limit with interval 6 , and this trend of 451 lowering temperatures continues until ca. $1200 \mathrm{cal}$ yr BP. These apparently cold conditions were 452 accompanied between 1800 and 900 cal yr BP by an increase in the estimated water depth of the 453 mire (Fig. 6). From about 900 cal yr BP until today, the altitude of the UFL increased fairly 454 regularly to reach its present-day level, together with a rapidly decreasing water depth of the 455 mire.

4.4. Microfluorescence-X $(\mu X R F)$

$\mathrm{Ti}$ and Fe records have a sub-annual (ca. 6-month) time resolution, with ca. 19'000 461 measurements each over the first $857 \mathrm{~cm}$ of core LLG-5. Ti and Fe data have been smoothed 
462 through a 14-point moving average for display purposes and are plotted as indicative of wet vs.

463 dry conditions (Fig. 6). The two curves show a high degree of similarity. We shall concentrate on

464 the curve of the very conservative $\mathrm{Ti}$, except in the upper part of the late Holocene where $\mathrm{Ti}$ 465 values are below the threshold of reliability.

466 The upper part of the YD (interval 1) is characterized by high Ti values indicative of important 467 rainfall. The transition from interval 1 to 2 (i.e., from YD to Holocene at ca. 11,410 cal yr BP) is 468 marked by a sudden drop in Ti values, i.e., a rapid decrease in rainfall, which remained low 469 during interval 2. Low values of $\mathrm{Ti}$ in interval 3 are indicative of low rainfall and these dry 470 conditions persisted in interval 4 with some minor variations until ca. 7500 cal yr BP. The 471 uppermost part of interval 4 between 7500 and 7000 cal yr BP is marked by a peak in rainfall. 472 Interval 5 is marked by an overall increase in the Ti signal with two maxima, one at around 5700 473 cal yr BP and the other one between ca. 5000 and 4200 cal $\mathrm{yr} \mathrm{BP}$, which corresponds to the 474 highest rainfall level during the Holocene. The Ti values start decreasing towards the top of 475 interval 5, implying decreasing rainfall. Interval $6(4000-2300 \mathrm{cal} \mathrm{yr} \mathrm{BP})$ is characterized by a 476 rapid drop in the Ti values, indicative of a rapid decrease in rainfall. During Interval 7 (2300477 present-day) the values of $\mathrm{Ti}$ are too low to be interpreted, and the Fe record can be used 478 instead. It indicates an overall low level of precipitations with some slightly wetter phases.

\section{Interpretation and environmental reconstruction}

\subsection{Lithology}

The threefold subdivision of the sedimentary sequence penetrated at the centre of the LLG Basin (Fig. 4) corresponds to major palaeoenvironmental changes. Unit 1 (tested by cores LLG-4, $487-5,-7,-8$ and -9$)$ is interpreted as periglacial deposits, probably corresponding to the phase of 488 glacier melting. This type of environment is encountered in present-day superpáramo clear-water 489 lakes like those encountered in the Sierra Nevada del Cocuy in the Eastern Cordillera of 
490 Colombia (N. Parra, pers. comm., 2011). No or very little vegetation surrounds these lakes. The 491 glacial nature of these deposits is confirmed by ages close to $17,000 \mathrm{cal} \mathrm{yr}$ BP obtained in the 492 uppermost part of the unit (Fig. 5). Unit 1 corresponds to the late Pleniglacial (Fig. 5)

493 The limit between units 1 and 2 is marked by an unconformity corresponding to a major 494 palaeoenvironmental change. The organo-mineral Unit 2 without vegetal fibres can be interpreted 495 as an environment of a few-metre deep páramo black lakes (Parra et al., 2010c). This unit 496 contains mineral mud associated to the deglaciation and mixed with organic matter from the 497 growing vegetation. Unit 2 contains at its base several tephra levels tentatively correlated by 498 Parra et al. (2010d) with the eruptive stages called Canalones and Romerales by Thouret et al. 499 (1995). According to the age model (Fig. 5) they are dated between 15,000 and 17,000 cal yr BP. 500 Unit 2 corresponds to the Lateglacial, with its upper part being equivalent to the YD (Fig. 5).

Unit 3 corresponds to the Holocene period during which the LLG depression was infilled 502 mainly by vegetal fragments and little minerals. It was covered by marshes, peat bogs and very 503 shallow, brackish páramo black lakes (Parra et al., 2010c). The thin tephra layer encountered in 504 cores LLG-2 to -9 at a depth of ca. $4 \mathrm{~m}$ (isochron a, figs. 4 and 5) has been previously interpreted 505 as the "Salamina" tephra related to the eruption of the Cerro Bravo volcano and dated at between 5066500 and $7200 \mathrm{yr}$ BP (Parra, 1991; Parra et al., 2010b), i.e., 7400 to $8000 \mathrm{cal}$ yr BP. According to 507 the age model obtained in LLG (Fig. 5), this ash layer appears younger with an age of ca. 6000 508 cal yr BP.

509 Apart from the limit between the glacial clays of the late Pleniglacial and the onset of the 510 organic-rich sedimentation in the Lateglacial (Fig. 4), the whole Lateglacial and Holocene 511 sequence in cores LLG-2 to -9 does not present any indication of unconformities or significant 512 hiatuses in the sedimentation. The 30 AMS ${ }^{14} \mathrm{C}$ datings obtained throughout this sequence 513 confirm the remarkable continuity of the deposition (Fig. 5). 
In this section we present a reconstruction of the Holocene climatic variability in LLG, which can be inferred from the biotic (arboreal and aquatic pollen) and abiotic ( $\mu \mathrm{XRF}$ ) proxies.

Time series analysis has been carried out on the ultra-high (sub-annual) resolution $\mu \mathrm{XRF}$ data. The Morlet wavelet spectrum (MWS) has been analyzed over the interval $12,000-0 \mathrm{cal}$ yr $\mathrm{BP}$ both for $\mathrm{Ti}$ and $\mathrm{Fe}$ and can be studied with respect to the palynological and geochemical precipitation proxies (Fig. 6 and Suppl. Fig. 2). The MWS permits the identification of changes in variance through time within selected frequency time bands. Yellow to red areas indicate a high degree of variance, and a black line surrounds regions of variance that exceed the $95 \%$ confidence level for a red noise process (at 4-16 yr period, the regions of significant variance are shown black rather than outlined). The MWS of Ti (Fig. 6) shows a high degree of cyclicity for phenomena in the millennial bands throughout the late YD and Holocene, whereas a high activity in the $500 \mathrm{yr}$ down to sub-decadal (i.e., ENSO) bands is restricted to more specific time intervals.

The Holocene record in Frontino is marked by rapid and significant changes in temperature 531 and precipitation. Temperatures may have varied a few degrees centigrade over less than a 532 century and changes in rainfall were either progressive or abrupt (Fig. 6). All proxies show that 533 the upper part of the YD (interval 1) was cold and wet. Between 12,000 and 11,410 cal yr BP, the 534 MWS of Ti displays a high variance from the millennial bands down to the ENSO band. The base 535 of the Holocene (interval 2, 11,410-10,700 cal yr BP) was warm and dry and the MWS does not 536 show much variance in the centennial to ENSO bands. Cold and dry conditions prevailed in 537 interval $3(10,700-9700 \mathrm{cal}$ yr BP) with some occasional high variance in the high frequencies 538 (e.g., ENSO band). Interval 4 (9700-6900 cal yr BP) was overall warm and can be interpreted as 539 the "Holocene thermal maximum" (e.g., Haug et al., 2001; Niemann et al., 2009; Renssen et al., 540 2009; Renssen et al., 2012; Wanner et al., 2014). It was interrupted by a colder break at around $5418000 \mathrm{cal}$ yr BP (Fig. 6), which might be an expression of the 8.2 ka event well known in the North 542 Atlantic (e.g., Alley and Agustsdottir, 2005; Rohling and Palike, 2005; Cheng et al., 2009). The 543 small offset in time might be due to inaccuracy of the age model or correspond to a real lag time 544 associated with the response of the tropics to this event. Interval 4 was overall dry until ca. 7500 545 cal yr BP (low Ti signal and low estimated water level in the mire). Some slightly wetter intervals 
546 might occur (visible in the Ti signal) and the MWS shows occasional high variance in the 547 centennial to ENSO bands. The period $7700-7500$ cal yr BP is very dry and marked by 548 dessiccation in the mire. This period coincides with a very low activity in the 500 yr to sub549 decadal bands of the MWS. The following period between 7500 and $4200 \mathrm{cal}$ yr BP is the wettest 550 of the Holocene and coincides with a climate colder than today between 7000 and $4200 \mathrm{cal} \mathrm{yr}$ 551 BP. The Ti signal highlights three rainfall maxima, between 7500 and 7000,5600 and 5300 and 5525000 and $4200 \mathrm{cal}$ yr BP. These maxima coincide with a high variability in the $500 \mathrm{yr}$ to sub553 decadal bands of the MWS. The first peak in rainfall (7500-7000 cal yr BP) coincides with the 554 decrease and near-disappearance of the driest aquatic vegetation in the mire (Fig. 6). The second and third peaks in rainfall are matched by an increase in the estimated water depth of the mire, which reaches a maximum between 5000 and 4200 cal yr BP. In the uppermost part of 557 interval 5 (from about 4200 cal yr BP), rainfall inferred from Ti (and Fe, Fig. 6 and Suppl. Fig. 2) 558 starts decreasing and continues to decrease rapidly in interval 6 (4000-2400 cal yr BP) to reach a 559 minimum between ca. 2800 and 2600 cal yr BP, when it coincides with a maximum in 560 temperature. This decrease in rainfall inferred from the geochemical proxies ( $\mathrm{Ti}$ and $\mathrm{Fe}$ ) matches 561 well the water level of the mire derived from local aquatic plants (Fig. 6). The rapid decrease in 562 rainfall in interval 6 coincides with a decrease in activity in the $500 \mathrm{yr}$ to ENSO bands of the 563 MWS. At ca. 2400 cal yr BP the UFL drops suddenly and remains low during most of interval 7 564 (2400-0 cal yr BP). Although this abrupt drop is probably climate-forced, the AP\% cannot be used 565 as a temperature proxy in interval 7 because of human impact (Flantua et al., 2016a): 566 anthropogenic deforestation during the last $2.3 \mathrm{kyr}$ around the Páramo de Frontino is supported 567 by the rapid decrease in Quercus and the significant increase in asteraceous shrub and grasses 568 as a consequence (Velásquez, 2005). Nevertheless, the rapid increase in AP\% over the last 200 569 years demonstrates a significant warming over this period (well-known from ice core records in 570 tropical South America (SA) (Thompson et al., 1995; Thompson et al., 2000) and from pollen 571 records in northern Ecuador (Bakker et al., 2008; Moscol Olivera and Hooghiemstra, 2010)). This 572 implies that the MAT, although it cannot be directly inferred from the AP\% because of human 573 impact, was lower than today for most of the last 2 kyr. During the last 2000 years, sedimentation 
574 in the LLG mire corresponds essentially to peat formation with very little mineral influx (extremely

575 low $\mathrm{Ti}$ and low Fe signals). This points to overall dry conditions, but minor wetter phases can be 576 detected in the Fe signal, which increases in intensity between ca. 2500 and 500 cal yr BP (Fig. 6 577 and Suppl. Fig. 2). The aquatic plants also show an increase in the estimated water depth, 578 especially between 1700 and 900 cal yr BP.

\section{Discussion}

\subsection{Local climate}

In this section, we discuss the relevance of our multiproxy approach to reconstruct the humidity/rainfall record of the YD and Holocene. We also discuss the contribution of time series analysis of $\mu \mathrm{XRF}$ data to the interpretation of climate mechanisms. Finally, we demonstrate the importance of testing the LLG sedimentary record in its optimal location with an accurate age model.

The contribution of multiproxy tools in palaeoenvironmental reconstruction has been emphasized by Flantua et al. (2015). In our study we base the reconstruction of humidity/rainfall

592 on a biotic (aquatic pollen) and abiotic ( $\mu$ XRF) proxy and can assess their (dis)advantages. $\mu$ XRF

593 measures the amount of chemical elements (in minerals) brought in the basin by runoff waters.

594 Therefore, this signal gives a precise "instantaneous" indication of the amount of rainfall in the 595 catchment area. By contrast, the local aquatic vegetation gives only an estimation of the water 596 depth in the mire with a time lag of an estimated decade minimally. Moreover, the two proxies 597 have a different temporal resolution: the pollen record between 20 to $35 \mathrm{yr}$, and $\mu \mathrm{XRF}$ a sub598 annual resolution. The latter is consequently more accurate and quite suited for time series 599 analysis. Finally, these two proxies are derived from two different cores and there might be some 600 offset between records because of the age model. The visual comparison between the high- 
601 resolution $\mu \mathrm{XRF}$ Ti curve and the water depth estimated from aquatic plants shows an overall 602 similarity (Fig. 6). In the YD, high rainfall coincides with a significant water depth in the mire. 603 Between 11,410 and 7500 cal yr BP, reduced rainfall coincides with a low water level in the mire. 604 During this period, the short peaks in rainfall observed in $\mu \mathrm{XRF}$ data are not registered in the 605 aquatic pollen record. Between 7500 and 4200 cal yr BP, the increase in rainfall inferred from Ti 606 and $\mathrm{Fe}$ is matched by an increase in the estimated water depth of the mire, which reaches a 607 maximum between 5000 and $4200 \mathrm{cal} \mathrm{yr} \mathrm{BP.} \mathrm{The} \mathrm{rapid} \mathrm{decrease} \mathrm{in} \mathrm{rainfall} \mathrm{between} 4200$ and $6082600 \mathrm{cal}$ yr BP coincides with a lowering water level in the mire. During the last 2600 years the 609 comparison between the two proxies is difficult because of the very low influx of minerals in the 610 mire. This comparison of proxies demonstrates that aquatic pollen-based records of past lake611 level changes can provide a valuable means to assess precipitation (Van Boxel et al., 2014; 612 Urrego et al., 2016), although they yield less precise results than high-resolution $\mu \mathrm{XRF}$.

613 The MWS of Ti and Fe (Fig. 6, Suppl. Fig. 2) shows a wide spectrum of frequencies in the 614 precipitation regime from millennial to annual scales. A high variance in the millennial bands 615 exists throughout the record. Millennial-scale climate variability in the Holocene is commonly 616 attributed to solar variability. Of all potential climate-forcing mechanisms, Mayewski et al (2004) 617 consider solar variability superimposed on long-term changes in insolation as most likely the 618 important forcing mechanism for rapid climate change in the Holocene. Most statistical analyses 619 find significant correlations between regional South American precipitation and Pacific sea620 surface temperatures (SSTs) (Cook, 2009), and millennial-scale fluctuations in SSTs correlate 621 with cosmogenic nuclide proxies of solar variations (Marchitto et al., 2010). Redistribution of 622 solar energy due to orbital forcing on a millennial timescale is the inferred cause of the 623 progressive southward shift of the ITCZ during the last 6000 years (Wanner et al., 2008). High 624 variance at multi-centennial to decadal timescales occurs in LLG during specific time intervals 625 from the YD till ca. 3000 cal yr BP (Fig. 6, Suppl. Fig. 2). Multi-centennial cycles during the 626 Holocene in the Peruvian Andes are attributed to solar variations (Bush et al., 2005). Decadal to 627 centennial dry-wet oscillations at the Lateglacial-Holocene transition in the Central Andes could 628 have been triggered by both solar and ENSO activity (Hernández et al., 2010). Recent climate 
629 model studies suggest that even low amplitude solar variations can affect climate on multi630 decadal to centennial timescales (Ammann et al., 2007). Finally, the precipitation regime in LLG 631 seems to be directly related to the activity of ENSO: the high variance in the 4-8 yr ENSO band 632 coincides with the intervals of high rainfall interpreted from $\mu \mathrm{XRF}$ or aquatic plants.

633 Velásquez and Hooghiemstra (2013) published the pollen record of core LLG-1. The age 634 model of this $17 \mathrm{kyr}$ long record relies on only six ${ }^{14} \mathrm{C}$ dates. Unfortunately, this core is located 635 on the flank of the basin (Fig. 2C) and penetrated a condensed sedimentary section with 636 hiatuses (Fig. 4). Consequently, it is difficult to establish a correlation with data used in the 637 present study, which originate from the well-dated, hiatus-free, deepest part of the basin (cores 638 LLG-2 and -5). The sharp transition between the YD and the Holocene at 11,410 cal yr BP in 639 LLG-2 is the only precise correlation point that can be established with core LLG-1, where a 640 similar change from a cold and wet YD to a warm and dry basal Holocene is observed at a 641 depth of ca. $565 \mathrm{~cm}$ (Velásquez and Hooghiemstra, 2013). Finally, the importance of sampling a 642 hiatus-free, stratigraphically continuous section (Van 't Veer et al., 2000; Groot et al., 2013) is 643 perfectly illustrated by the following observation: in LLG-1, the first indication of human impact 644 (deforestation of Quercus, Podocarpus and Weinmannia and increase in asteraceous shrub and grasses) is interpreted at ca. $620 \mathrm{cal}$ yr BP, whereas in the centre of the basin human impact is shown by the rapid decrease in Quercus and the significant increase in asteraceous shrub and grasses (Velásquez, 2005) since ca. 2300 cal yr BP!

\subsection{Regional correlations}

The LLG record shows the first Holocene multiproxy record in the neotropics at a neardecadal to sub-annual scale (Flantua et al., 2015). With such a resolution one might try to

654 distinguish purely local variations from a more regional signal. In this section, we present a 655 comparison of Frontino data with selected northern South American palaeoclimatic records (Fig. 656 7) of Lateglacial and Holocene times to attempt a better understanding at the regional scale. 
Regional correlations face several problems. The topography of the Andes plays an important role, in particular when analyzing humidity records (Urrego et al., 2016). Moreover, the quality and accuracy of the data differ considerably from one record to another, as well as the precision of the age model (Flantua et al., 2016b). Except for the marine Cariaco Basin in the Venezuelan 661 Caribbean Sea (Haug et al., 2001; Lea et al., 2003; Petersen and Haug, 2006), selected 662 comparison sites are high-altitude locations distributed along a N-S Andes transect (Fig. 1). 663 Temperature and humidity data at these sites are derived essentially from pollen records, except 664 for the humidity data in the Laguna Los Anteojos (Venezuela, Stansell et al., 2010) and Laguna 665 Rabadilla de Vaca (Equator, Niemann et al., 2009) where humidity information originates from Ti XRF records, and in the Huascaran ice core (Peru, Thompson et al., 1995) where temperature data come from oxygen isotope ratio $\delta^{18} \mathrm{O}$ measurements. All pollen records have an over $100 \mathrm{yr}$ resolution, except for record La Cocha in Colombia (González-Carranza et al., 2012) with a 25 yr resolution. The Cariaco site is of particular interest because of its XRF data with a $5 \mathrm{yr}$ resolution 670 (Haug et al., 2001 ; Petersen and Haug, 2006), which provide the best precipitation proxy in the 671 coastal Venezuelian cordilleras for correlation with Frontino. Moreover, Cariaco is located in the 672 Atlantic (Caribbean Sea) and its latitudinal position is close to that of Frontino, making it a very 673 valuable correlation point to try to distinguish Atlantic vs. Pacific-driven climatic influence. Both sites are located in the narrow band of low-level wind convergence over the equatorial oceans 675 where the seasonal migration of the ITCZ primarily affects coastal areas and northernmost SA 676 (Flantua et al., 2016a). A detailed comparison between the two sites will be discussed separately 677 in the next section.

678 The rapid increase in temperature at ca. 11,410 yr BP in LLG (Fig. 6) is interpreted as 679 reflecting the termination of the South American equivalent of the YD cool period, referred to as 680 the « El Abra stadial » in Colombia (Van der Hammen and Hooghiemstra, 1995; Van 't Veer et 681 al., 2000). The explanation for this abrupt global temperature shift favours either tropical (Clement 682 et al., 2001) or high latitude (Broecker, 2006) ocean-atmosphere systems as the dominant driving 683 mechanisms. Whatever the initial cause of the YD, the tropics must have played an important role 684 in modulating the climate system during and at the termination of the event (Stansell et al., 2010). 
685 In the Northern Hemisphere, the YD cold reversal occurs between about 12,850 and 11,650 cal $686 \mathrm{yr}$ BP (Rasmusen et al., 2006). In Frontino, the end of the YD is dated at ca. 11,410 cal yr BP. In 687 tropical Central and South America, the YD cold period is observed at several sites, but precise 688 datings in non-condensed sections are lacking and its upper boundary is still insufficiently known 689 (Van der Hammen and Hooghiemstra, 1995; Van 't Veer et al., 2000). In this respect, Frontino 690 provides a new high-resolution data point for precisely dating the end of the YD in this region.

692 south as Peru (Fig. 7). It is normally registered as a dry period, except in the high-altitude sites of 693 Frontino in Colombia and Laguna Los Anteojos in the Mérida Andes of Venezuela in the north, 694 and of Laguna Rabadilla de Vaca and Laguna Pallcacocha/Chorreras (Hansen et al., 2003) in 695 southern Ecuador. There is a striking difference between Frontino and Cariaco where XRF data 696 show respectively a very wet and a very dry YD (Fig. 8).

697 During the period of $11,500-8000$ cal yr BP, most of the sites show an increase in 698 temperature (Fig. 7). This is interpreted by the authors as the "Holocene thermal maximum" (e.g., 699 Haug et al., 2001; Renssen et al., 2012; Wanner et al., 2014). In Frontino and Cariaco, the overall 700 increase is significant right from the beginning of the Holocene, whereas the onset of this 701 warming may occur later or be more gradual or irregular in the other sites. Humidity records are 702 more contrasted and depend highly of the geographical location. The most striking feature is 703 observed between Frontino, the Laguna Los Anteojos (Mérida Andes) and Cariaco, where Ti 704 XRF data are available: at the first two locations conditions become dry, whereas, by contrast, 705 the Caribbean area becomes gradually wetter (Fig. 7). Similarly to Cariaco, other sites in Central 706 America show wet conditions at the beginning of the Holocene, e.g., in Panama (Piperno and 707 Jones, 2003) and Costa Rica (Islebe et al., 1995). This results from the northward migration of 708 the ITCZ after the YD (Haug et al., 2001). The dry conditions in Frontino (and possibly the Mérida 709 Andes) may be Pacific-driven and related to the low activity of ENSO (Fig. 6). Other sites further 710 south (Fig. 7) in Colombia (Lake Fúquene in the Eastern Cordillera), Ecuador (Laguna Rabadilla 711 de Vaca) and Peru (Laguna de Chochos) show wetter conditions possibly related to moisture 712 supply by trans-Amazonian air flows (Fu et al., 2001; Vizy and Cook, 2007). 
During the period of $8000-4000$ cal yr BP, most of the records in Colombia, Venezuela,

714 Ecuador and Peru (Fig. 7) show a temperature decrease at some stage, which is interpreted as 715 the end of the "Holocene thermal maximum" (Frontino, Mérida Andes, Cariaco, Rabadilla de 716 Vaca, Lago la Compuesta, Huascaran Glacier). Both Frontino and Cariaco show a significant 717 cooling between 6000 and 4000 cal yr BP. Humidity variations are more difficult to compare, 718 because the accuracy of the proxy used differs considerably. An overall decrease in precipitation 719 is observed in Cariaco between 7000 and 4000 cal yr BP. A similar decrease in moisture is also 720 registered in the Mérida Andes of Venezuela (Laguna Verde Alta, Rull et al., 2005) and in Central 721 America in Costa Rica (Islebe et al., 1995) and the Yucatan Peninsula (Carrillo-Bastos et al., 722 2010). This is interpreted as resulting from the southward migration of the ITCZ (Haug et al., 723 2001). By contrast, Frontino shows an overall increase in precipitations with a maximum between ca. 5000 and 4500 cal yr BP coinciding with an increased activity of ENSO (Fig. 6). In the Laguna 725 Rabadilla de Vaca (southern Ecuador), the maximum of precipitations occurs between 6000 and 7263500 cal yr BP (Fig. 7). This could also be the effect of increased ENSO activity, or humidity 727 supply from the Amazon. East of the Colombian Andes in the lowlands, the period of $8000-4000$ 728 cal yr BP is marked by alternations of wet and dry periods, maybe becoming wetter towards the 729 top (Behling and Hooghiemstra, 2000; Velez et al., 2006).

730 The palaeoclimatic reconstruction of the period of $4000-0$ cal yr BP in Frontino has been 731 derived from pollen record by Velásquez (2005). It is complemented here with new $\mu$ XRF data 732 and related statistics (Fig. 6 and Suppl. Fig. 2). With respect to temperature, the model based on 733 the AP\% in Frontino shows a significant period of warming between 4000 and 2500 cal yr BP. 734 This temperature increase is accompanied by dry conditions (Fig. 6). This increase is difficult to 735 confirm in the Colombian Andes because of lack of high-resolution records (Flantua et al., 2015), 736 except in the south, in Lake La Cocha, where warm conditions seem to prevail until 1500 cal yr 737 BP (Fig. 7) and in the Eastern Cordillera where warm conditions lasted at least until $3.2 \mathrm{kyr}$ 738 (Fúquene-2, Bogotá-Angel et al., 2011). In southern Ecuador (Lag. Rabadilla de Vaca) and in 739 Peru (Lago La Compuesta, Huascaran Glacier), the late Holocene is interpreted as a cold period 740 (Fig. 7). After 2400 cal yr BP, temperatures in Frontino drop rapidly, but MAT cannot be 
741 estimated because of the human impact (deforestation) observed from ca. 2300 cal yr BP (Fig.

742 6). Temperature increases rapidly over the last 200 years (Fig. 7), as also observed in southern 743 Colombia (La Cocha) and Peru (Huascaran glacier). Humidity data show overall dry conditions in

744 Frontino, with some oscillations observed in $\mu$ XRF (Fe data) and pollen data (Fig. 6). Similarly, 745 overall dry conditions in the late Holocene are also registered in Cariaco and Central America 746 (Costa Rica and Yucatan peninsula). This is related to the southern position of the ITCZ (Haug et 747 al., 2001).

748 Therefore, although the quality of the data is disparate, these regional correlations tend to 749 highlight the influence of at least three mechanisms that have been proposed to explain Holocene 750 climate variability in northern SA: the northward/southward migration of the ITCZ, the varying 751 activity of ENSO and the humidity supply by trans-Amazonian air flows.

752

753

6.3. Correlation with the Cariaco Basin and implications for regional climate mechanisms

755

In this section, we focus on the high-resolution data of Frontino and Cariaco, in order to better understand the climate mechanisms that affected these areas and the potential connections between Pacific and Atlantic climates during the Holocene (Fig. 8).

In tropical northern SA, oceanic-atmospheric systems regulate present-day and past climatic

760 variations. The most important system is the Atlantic ITCZ driven by high latitude forcing in the

761 northern Atlantic. Changes in its mean position best explain precipitation variation (Petersen and 762 Haug, 2006; Flantua et al., 2016a). This high-latitude Atlantic-driven forcing mechanism interacts 763 with another oceanic-atmospheric system characterizing the tropical Pacific, i.e., the ENSO 764 (Vuille and Werner, 2005; Vuille and Garreaud, 2012). In the Colombian Andes during the last 7652000 years, more than two thirds of the temperature variability on interannual scales can be 766 explained by ENSO, which also leads to the strongest modern precipitation anomalies (Flantua et 767 al., 2016a). These two mechanisms are today the best explanations for the large and abrupt 768 climate changes characterizing the Lateglacial and Holocene in northernmost SA. Both 
mechanisms are important, but the degree to which each contributes is timescale dependent and

770

771

there is a need for more high-resolution palaeoclimatic records in areas exposed to ITCZ and ENSO influences (Petersen and Haug, 2006).

In this respect, the LLG record is ideally located because Frontino is exposed to the influence of both oceans. It is so far the only high-altitude, high-resolution, multiproxy record in the Western Cordillera of Colombia (Flantua et al., 2015). Because of its high-resolution (5 yr) XRF data, the Cariaco Basin remains the best comparison point as rainfall proxy (Fig. 8) in northern SA. Moreover, SST in the tropical Atlantic (Lea et al., 2003) can be used as comparison for temperature variations (although with a resolution of only $200 \mathrm{yr}$ ).

As far as temperature is concerned, the interpretation obtained from pollen record in Frontino fits the overall picture known in this region. A cold YD equivalent (El Abra stadial in Colombia, Van der Hammen and Hooghiemstra, 1995; Van 't Veer et al., 2000) is present, with an estimated MAT some $3.5^{\circ} \mathrm{C}$ lower than today. This figure can be compared with that of ca. $5^{\circ} \mathrm{C}$ in the Eastern Cordillera of Colombia (Groot et al., 2011), of $3^{\circ} \mathrm{C}$ suggested by Van 't Veer et al. (2000) for Costa Rica, Guatemala and Colombia, and that of $2.2-2.9^{\circ} \mathrm{C}$ in the Venezuelan Andes (Stansell et al., 2010). An abrupt increase in temperature marks the base of the Holocene in Frontino, similarly to that observed in SST of Cariaco (Fig. 8). An interval of overall higher temperatures straddles the period of ca. 10,000 till $6500 \mathrm{cal}$ yr BP in Frontino and can be referred to as the «Holocene thermal maximum ». It is also well expressed and synchronous in Cariaco (Fig. 8). It is encountered in most of the sites used for comparison (Fig. 7), although its actual onset and duration seem to vary from site to site (because of location, local climatic conditions, time resolution and accuracy of age model). The period of $6000-4000$ cal yr BP in Frontino becomes considerably colder with MAT possibly $2.5^{\circ} \mathrm{C}$ lower than today. This cold period coincides with a cold interval observed from SST in the Caribbean (Fig. 8). In the upper part of the Holocene, the temperature model of LLG (Fig. 8) suggests a temperature maximum culminating at ca. $3000 \mathrm{cal} \mathrm{yr} \mathrm{BP.} \mathrm{In} \mathrm{Cariaco,} \mathrm{SST} \mathrm{also} \mathrm{shows} \mathrm{a} \mathrm{high} \mathrm{at} \mathrm{around} 3000 \mathrm{cal}$ yr BP. From ca. 2400 cal yr BP, colder conditions probably prevailed in Frontino, but cannot be properly estimated because of human impact (deforestation) after 2300 cal yr BP (Fig. 8). Cold conditions 
are also encountered during the last 3000 years in Ecuador (Laguna Rabadilla de Vaca and in core G15-II in northern Ecuador, Bakker et al., 2008) and Peru (Huascaran ice core, Fig. 7). In the Carribean Sea warm conditions prevailed during the last 2000 years (Fig. 8). $\mu \mathrm{XRF}$ data in Frontino (supported by the aquatic pollen proxy, Fig. 8) show a very abrupt change from a wet YD to a much drier Holocene. By contrast, XRF data in Cariaco show the 802 opposite (Haug et al., 2001, Petersen and Haug, 2006): the YD is dry and the transition to a wet 803 Holocene is progressive (Figs. 7 and 8). Similarly, in the Yucatan Peninsula (Lake Peten Itza), 804 Hodell et al. (2008) observe a dry YD followed by the return to wetter conditions in the early 805 Holocene. Both in Cariaco and Yucatan (Caribbean Sea), authors explain the dry conditions of 806 the YD through the latitudinal displacement towards the south of the mean position of the ITCZ during the last glacial maximum. With the warming phase at the base of the Holocene, the ITCZ migrated northwards, resulting in progressively wetter conditions at both sites. The latitudinal 809 position of Frontino is close to that of the coastal Venezuelian cordilleras draining into the Cariaco 810 Basin (Fig. 1). If Frontino precipitation regime at the YD-Holocene transition had been directly 811 influenced by the ITCZ, one would expect a similar signal to that encountered in Cariaco 812 (similarly to what happens during the period of 4500-3500 cal yr BP, see below). Moreover, the 813 abrupt YD-Holocene change in precipitation in Frontino looks quite different from the gradual 814 transition observed between 4500 and 3500 cal yr BP (Fig. 8). Therefore, we postulate that the 815 moisture regime in the YD and early Holocene in Frontino might have been more under the 816 influence of the Pacific Ocean (ENSO, Choco Jet) than under that of the Atlantic Ocean 817 (influence of ITCZ dominant in the Caribbean Sea). The MWS of Ti in Frontino (Figs. 6 and 8) 818 shows high variance in the ENSO band for the last 600 years of the YD. In the early Holocene, all 819 high frequencies decrease in variance, with only some short events affecting the ENSO band. 820 Moreover, high variance in the millennial bands is observed in Frontino during the late YD and 821 early Holocene (Fig. 8). This could be related to the influence of solar forcing with millennial-scale 822 fluctuations, as demonstrated in the Pacific Ocean during the early Holocene (Marchitto et al., 823 2010). 
Cariaco and Frontino exhibit contrasting rainfall patterns between 11,400 and 4000 cal yr BP

825 (Fig. 8). In Cariaco, increasing rainfall in the early Holocene is followed by a precipitation 826 maximum coinciding with the Holocene thermal maximum between ca. 10,000 and $7000 \mathrm{cal} \mathrm{yr}$ 827 BP. This is consistent with the postulated northward migration of the ITCZ after the YD. The correlation of this wet and warm interval in Cariaco with La Niña-like wet conditions in the eastern 829 equatorial Pacific (Marchitto et al., 2010) is an argument to interpret the existence of already 830 existing ENSO teleconnections at that time (Stott et al., 2002). From 7000 cal yr BP, 831 precipitations in Cariaco start to decrease slightly until $4000 \mathrm{cal}$ yr BP and drop rapidly afterwards 832 (Fig. 8). This is interpreted as reflecting the southward migration of the ITCZ leading to dry 833 conditions in the late Holocene. The picture in Frontino is different. $\mu$ XRF data (supported by 834 aquatic pollen proxy, Fig. 8) show an overall increase in precipitation between 11,400 and 4500 835 cal yr BP with a maximum centered over 5000-4500 cal yr BP. Superimposed on this general 836 trend, both $\mathrm{Ti}$ and Fe data show oscillations at millennial and sub-millennial timescales (Fig. 8). 837 The MWS of Ti displays continuous high variance in the millennial bands during this period (Fig. 6 838 and 8). In the ENSO band, intervals of high activity are very intermittent but increase in 839 frequency, particularly between 7500 and 4000 cal yr BP. We interpret these data as reflecting 840 the dual signature of the ITCZ and ENSO: the overall increase in rainfall would be the result of 841 the southward migration of the ITCZ, whereas the higher frequency cycles would be linked to 842 ENSO. These observations in Frontino can be compared with those of Moy et al. (2002), who 843 have interpreted in the Laguna Pallcacocha in Ecuador that warm ENSO events became more 844 frequent throughout the Holocene, with a superimposed trend showing periods of high and low 845 ENSO activity at timescales of 2000 years. Orbitally-driven external forcing with a 1000/2500 yr 846 cyclicity (Debret et al., 2009 ; Marchitto et al., 2010) may also be an important factor. The 847 influence of ENSO variability after 7000 cal yr BP has also been recognized in Lake La Cocha in 848 the southern Colombian Andes (González-Carranza et al., 2012).

849 The rainfall record in Cariaco and Frontino over the last 5000 years highlights the dual 850 influence of ITCZ and ENSO over the climate in both areas (Fig. 8). The XRF record in Cariaco 851 illustrates the rapid change towards dry conditions after ca. 3000 cal yr BP. This decrease in 
852 rainfall was associated with the southward shift of the ITCZ (Haug et al., 2001; Petersen and 853 Haug, 2006) and coincided with an increase in ENSO activity. The latter was probably related to 854 a precessional control (Clement, 1999; Clement et al., 2001), leading to the prevalence of dry El 855 Niño events in the late Holocene. In lake sediments from Ecuador, Rodbell et al. (1999) showed 856 that modern ENSO periodicities were established only after about 5 ka. Haug et al. (2001) have 857 related these observations to precessionally-forced insolation changes. The latter would have 858 directly forced the southward migration of the ITCZ, but also increased the prevalence of El Niño 859 through the Holocene. This would have further amplified the southward shift of the ITCZ while 860 adding a higher frequency component to its latitudinal variations. The MWS in LLG indicates that 861 between 5100 and $4300 \mathrm{cal}$ yr BP both Ti and Fe signals show the highest variance of the whole 862 Holocene in the high frequency bands (e.g., ENSO), which coincides with the maximum of rainfall 863 (Suppl. Fig. 2 and Fig. 8). Between 4300 and 3500 cal yr BP, the significant decrease in rainfall in 864 both areas results from the southward migration of the ITCZ, but also coincides with a strong 865 ENSO variability (Fig. 8, Haug et al., 2001). Between 3500 and 260 cal yr BP, although the Fe 866 signal is very stable in variance, it is only perturbed by frequent short events in the ENSO band.

867 Therefore, comparison of rainfall between Frontino and Cariaco suggests that climate in the 868 northern part of the Western Cordillera was probably Pacific-driven in the YD and early Holocene 869 with little influence of the Atlantic-driven ITCZ. From ca. $8000 \mathrm{cal} \mathrm{yr} \mathrm{BP,} \mathrm{both} \mathrm{areas} \mathrm{seem} \mathrm{to} \mathrm{be}$ 870 under the dual influence of ENSO and ITCZ, which highlights the existing teleconnections 871 between tropical Pacific and Atlantic climate (Fig. 8).

\section{Conclusions}

We have analyzed the stratigraphically continuous sedimentary archive of the LLG mire in the

877 northernmost part of the Colombian Western Cordillera using two proxies, which permitted the 878 study of the biotic (pollen) and abiotic ( $\mu \mathrm{XRF}$ ) components of this high-mountain ecosystem. The 879 time interval studied covers the last $11,500 \mathrm{cal}$ yr BP and comprises the uppermost YD and the 
880 Holocene. The studied interval is accurately dated by a robust age model. The ultra-high 881 resolution of the results (20-35 yr for pollen, ca. 6-months for the $\mu \mathrm{XRF}$ ) makes this record unique 882 for the study of Holocene climate variability in northwesternmost SA, where climate dynamics is 883 essentially governed by the interaction between oceanic-atmospheric systems of the ENSO and 884 ITCZ.

885 We have demonstrated the important climate variability in Frontino at various timescales (Fig.

886 6). The transition from the YD to the Holocene was very rapid and is accurately dated at 11,410 887 cal yr BP. Throughout the Holocene, estimated MAT varied from $2.5^{\circ} \mathrm{C}$ lower up to $3.5^{\circ} \mathrm{C}$ higher 888 than today with an alternation of warm and cold periods. The last 2400 years were probably 889 colder than today, but human impact affects the pollen record from $2300 \mathrm{cal}$ yr BP. We have 890 reconstructed the precipitation regime using both pollen and $\mu$ XRF data. The latter have been 891 analyzed by spectral analysis, which shows rainfall periodicities in the millennial bands 892 throughout the Holocene, whereas centennial down to ENSO band periodicities are observed in 893 more specific intervals, which coincide with increased precipitation (Fig. 6). Correlations with 894 other selected sites in tropical northwestern SA have confirmed that ITCZ (Atlantic-driven) and 895 ENSO (Pacific-driven) are the main mechanisms influencing the climate in this area. We have 896 used the marine Cariaco Basin in Venezuela as the best reference correlation site, because of its 897 high-resolution XRF data and its location in the Atlantic climate realm. The influence of ENSO 898 and ITCZ varied over time in the two locations, with an additional external forcing due to solar 899 radiation which influences periodicities from millennial down to decennial time scales. During the 900 YD and early Holocene, we have interpreted the climate in Frontino as Pacific-driven (strong 901 influence of ENSO) and that in Cariaco as Atlantic-driven (dominated by the position of ITCZ). 902 From ca. 8000 cal yr BP until now, both areas show the dual influence of ITCZ and ENSO and 903 the existing teleconnections between Pacific and Atlantic oceans climate (Fig. 8).

904 We have compared the humidity record of aquatic plants with the rainfall proxy provided by $905 \mu \mathrm{XRF}$ of Ti and Fe (Fig. 6). Because of its sub-annual resolution, $\mu \mathrm{XRF}$ is much more precise, but 906 overall it correlates well with the aquatic pollen information. This demonstrates that climate 907 reconstructions from pollen record should not only focus on temperature, but also include 
908 information about precipitation, which is an equally important parameter (Van Boxel et al., 2014).

909 Our study has illustrated the value of multiproxy-based research in palaeoclimatic investigations

910 (Flantua et al., 2016a). We have demonstrated the value of ultra-high resolution $\mu$ XRF and

911 advocate its use as rainfall proxy in future multiproxy studies. It provides high-resolution time

912 series that can be explored with frequency analysis and provide support for climate-driving

913 mechanisms (Flantua et al., 2016a). Ongoing research (Monsalve, 2015) aims at testing in

914 Frontino the same multiproxy high-resolution approach on the Lateglacial interval from 17,000 till

91511,500 cal yr BP. Once completed, this Lateglacial study will be coupled with our present

916 Holocene data and provide the most accurate, stratigraphically continuous record of the last 17

917 kyr in NW Colombia. The continuous sedimentary sequence in LLG should also be investigated

918 by other biotic climate proxies, such as diatoms and chironomids. Finally, similar multiproxy

919 investigations should be undertaken on lower altitude sites in the Western Cordillera of Colombia.

920

921

922

\section{Acknowledgements}

924

925 The authors are indebted to the authorities of the Parque Nacional Natural las Orquídeas for their

926 help in facilitating the various field campaigns to the Páramo de Frontino. PM thanks the

927 Palaeoecology Laboratory of the National University of Colombia in Medellín and the Institute for

928 Biodiversity and Ecosystem Dynamics (IBED) of the University of Amsterdam (Holland) for the

929 use of their palynological reference collections. GG thanks Gerald Haug for providing the Ti and

930 Fe data from the Cariaco Basin. All authors are extremely grateful to Henry Hooghiemstra for his

931 extensive review of a former version of this manuscript. They also thank Valenti Rull for his

932 comments. This research has been supported by the Swiss National Science Foundation (grant 933 no. 200020-112320).

934 


\section{References}

936

937

938

939

940

941

942

943

944

945

946

947

948

949

950

951

952

953

954

955

956

957

958

959

960

961

962

963

964

965

Alley, R.B., Ágústsdóttir. A.M., 2005. The 8k event: cause and consequences of a major Holocene abrupt climate change. Quat. Sci. Rev. 24,1123-1149.

Ammann, C.M., Joos, F., Schimel, D.S., Otto-Blisner, B.L., Tomas, R.A., 2007. Solar influence on climate during the past millennium: results from transient simulations with the NCAR Climate System Model. Proceedings of National Academy of Sciences USA 104, 3713-3718.

Bakker, J., M. Moscol Olivera, M., Hooghiemstra, H., 2008. Holocene environmental change at the upper forest line in northern Ecuador. The Holocene 18, 877-893.

Behling, H., and H. Hooghiemstra. 2000. Holocene Amazon rainforest-savana dynamics and climatic implications: high-resolution pollen record from Laguna Loma Linda in eastern Colombia. J. Quat. Sci. 15, 687-695.

Bogotá-Angel, R.G., 2011. Pleistocene centennial-scale vegetational, environmental and climatic change in the Colombian Andes: based on biotic and abiotic proxy analyzes from Lake Fúquene sediments. Ph D Thesis. Institute for Biodiversity and Ecosytems Dynamic (IBED), University of Amsterdam, 144 pp. Bogotá-Angel, R.G., Groot, M.H.M., Hooghiemstra, H., Lourens, L.J., Van der Linden, M., Berrio, J.C., 2011. Rapid climate change from north Andean Lake Fúquene pollen records driven by obliquity: implications for a basin-wide biostratigraphic zonation. Quat. Sci. Rev. 30, 3321-3337.

Boom, A., Marchant, R., Hooghiemstra, H., Sinninghe Damsté, J.S., 2002. CO2- and temperature controlled altitudinal shifts of C4- and C3-dominated grasslands allow reconstruction of paleoatmospheric pCO2. Palaeogeogr., Palaeoclimatol., Palaeoecol. 177, 151-168.

Bradbury, J.P., Leyden, M., Salgado-Labouriau, M., Lewis, W.M., Schubert, C., Binford, M.W., Frey, D.G., Whitebread, D.R., Weibezahn, F.H., 1981. Late Quaternary environmental history of Lake Valencia, Venezuela. Science 214, 1299-1305.

Broecker, W.S., 2006. Was the Younger Dryas triggered by a flood? Science 312, 1146-1148.

Brunschön, C., Behling, H., 2010. Reconstruction and vizualisation of upper forest line and vegetation changes in the Andean depression region of southeastern Ecuador since the last glacial maximum A multi-site analysis. Rev. Palaeobot. Palynol. 163,139-153.

Bush, M.B., Hansen, B.C.S., Rodbell, D.T., Seltzer, G.O., Young, K.R., Leon, B., Abbott, M.B., Silman, M.R., Gosling, W.D., 2005. A 17.000-yr history of Andean climate and vegetation change from Laguna de Chochos, Peru. J. Quat. Sci. 20, 703-714. 
966 Carrillo-Bastos, A., G.A. Islebe, N. Torrescano-Valle, González, N.E., 2010. Holocene vegetation and climate history of central Quintana Roo, Yucatán Península, Mexico. Rev. Palaeobot. Palynol. 160, 189-196.

969 Cheng, H., Fleitmann, D., Edwards, R.L., Wang, X., Cruz, F.W., Auler, A.S., Mangini, A., Wang, Y., Kong, X., Burns, S.J., Matter. A., 2009. Timing and structure of the $8.2 \mathrm{kyr}$ B.P. event inferred from $\delta 180$ records of stalagmites from China, Oman, and Brazil. Geology 37,1007-1010.

Cleef, A.M. 1981. The vegetation of the Páramos of the Colombian Cordillera Oriental. Dissertationes Botanicae 61, 1-320. Cramer, Vaduz.

Cleef, A.M., Hooghiemstra, H., 1984. Present vegetation of the area og the high plain of Bogotá. Dissertationes Botanicae 79, 42-66. Cramer, Vaduz.

Cleef, A.M., J.O. Rangel, S. Salamanca, C.L. Ariza, Van. Reenen, G. B. A., 2005. La vegetación del páramo del Macizo de Tatamá, cordillera Occidental de Colombia. In : Van der Hammen,T., Rangel, J.O., Cleef, A.M. (Eds). La Cordillera Occidental Colombiana, transecto Tatamá. Estudios de Ecosistemas Tropoandinos, Berlin-Suttgart 6, 377-468.

Clement. A.C. 1999. Orbital controls on the El Nino/Southern Oscillation and the tropical climate. Paleoceanography 14, 441-456.

Clement, A.C., M.A. Cane, Seager,R., 2001. An orbitally driven tropical source for abrupt climate change. Journal of Climate 14, 2369-2375.

Cook, K.H., 2009. SAn climate variability and change: remote and regional forcing processes. In:

Cuatrecasas, J., 1958. Aspectos de la vegetación natural de Colombia. Revista de la Academia Colombiana de Ciencias Exactas, Físicas y Naturales 10, 221-264.

Debret, M., D. Sebag, X. Crosta, N. Massei, J.R. Petit, E. Chapron, Bout-Roumazeilles, V., 2009. Evidence 991 from wavelet analysis for a mid-Holocene transition in global climate forcing. Quat. Sci. Rev. 28,

993 Espinal, L.S., 1992. Geografía ecológica de Antioquia. Zonas de vida. Universidad Nacional de Colombia, 994 Medellín, 146 pp. 
995 Espinal, S., Boeke, J., McElroy, J., 1983. Notas sobre la flora del páramo de Frontino (Urrao). Gallencia 13, 85-88.

997 Faegri, K., Iversen, J., 1989. Textbook of pollen analysis. 4th ed., Wiley, Chichester, 328 pp.

998 Farge, M., 1992. Wavelet transforms and their applications to turbulence. Annual Review of Fluid $999 \quad$ Mechanics 24, 395-458.

1000 Flantua, S., Hooghiemstra, H., Grimm, E.C., Behling, H., Bush, M.B., González-Arango, C., Gosling, W., 1001 Ledru, M.-P., Lozano-García, S., Maldonado, A., Prieto, A., Rull, V., Van Boxel, J.H., 2015. Updated 1002 site compilation of the Latin American Pollen Database; challenging new research. Review Palaeobotany Palynology 223, 104-115.

1005

1006

Flantua, S.G.A., Blaauw, M., Hooghiemstra, H., 2016b. Geochronological database and classification system for age uncertainties in Neotropical pollen records. Climate of the Past 12, 387-414.

Fox, J., Andersen,R., 2005. Using the R statistical computing environment to teach social statistics courses. Department of Sociology, McMaster University, 36 pp.

Fu, R., Dickinson, R.E., Chen, M., Wang, H., 2001. How do tropical sea surface temperatures influence the seasonal distribution of precipitations in the equatorial Amazon ? Journal of Climate 14, 4003-4026.

Gentry, A.H., 1995. Patterns of diversity and floristic composition in neotropical montane forests. . In: Churchill, S.P., Balslev, H., Forero, E. and Luteyn, J.L. (eds), Biodiversity and conservation of

1017 González, E., Van der Hammen, T., Plint, R.F., 1965. Late Quaternary vegetational sequence in Valle de Lagunillas, Sierra Nevada del Cocuy. Colombia Leidse Geology 32, 157-182.

1019 González-Carranza, Z., Hooghiemstra, H., Vélez, M.I., 2012. Major altitudinal shifts in Andean vegetation on the Amazonian flank show temporarily loss of biota in the Holocene. The Holocene 22, 12271241.

Grimm, E.C. 1987. CONISS: a FORTRAN 77 program for stratigraphically constrained cluster analysis by the method of incremental sum of squares. Computers and Geosciences 13,13-35. 
1024 Groot, M.H.M., Bogotá, R.G., Lourens, L.J., Hooghiemstra, H., Vriend, M., Berrio, J.C., Tuenter, E. et al.,

1025

1026

1027

1028

1029

1030

1031

1032

1033

1034

1035

1036

1037

1038

1039

1040

1041

1042

1043

1044

1045

1046

1047

1048

1049

1050

1051

1052 2011. Ultra-high resolution pollen record from the northern Andes reveals rapid shifts in montane climates within the last two glacial cycles. Climate Past 7, 299-316.

Groot, M.H.M., Hooghiemstra, H., Berrio, J.-C., Giraldo, C., 2013. North Andean environmental and climatic change at orbital to submillennial time-scales: vegetation, water-levels, and sedimentary regimes from Lake Fúquene during 130-27 ka. Rev. Palaeobot. Palynol. 197, 186-204.

Hansen, B.C.S., D.T. Rodbell, G.O. Seltzer, B. León, K.R. Young, and M. Abbott. 2003. Late-glacial and Holocene vegetational history from two sites in the western Cordillera of southwestern Ecuador. Palaeogeogr., Palaeoclimatol., Palaeoecol. 194, 79-108.

Haug, G.H., Highen, K.A., Sigman, D.M., Peterson, L.C., Röhl, U., 2001. Southward migration of the Intertropical Convergence Zone through the Holocene. Science 293, 1304-1308.

Haug, G.H., Günther, D., Petersen, L.C., Sigman, D.M., Hughen, K.A., Aeschlimann, B., 2003. Climate and the collapse of Maya civilization. Science 299, 1731-1735.

Helmke, J.P., Bauch, H.A., Röhl, U., Mazaud, A.. 2005. Changes in sedimentation patterns of the Nordic seas region across the mid-Pleistocene. Marine Geology 215, 107-122.

Hernández,A., Giralt, S., Bao, R., Sáez, A., Leng, M.J., Barker, P.A., 2010. ENSO and solar activity signals from oxygen isotopes in diatom silica during late glacial-Holocene transition in Central Andes $\left(18^{\circ} \mathrm{S}\right)$. J. Paleolimnol. 44, 413-429.

Hodell, D.A., F.S. Anselmetti, D. Ariztegui, M. Brenner, J.H. Curtis, A. Gilli, D.A. Grzesik, T.J. Guilderson, A.D. Müller, M.B. Bush, A. Correa-Metrio, J. Escobar, Kutterolf, S., 2008. An 85-ka record of climate change in lowland Central America. Quat. Sci. Rev. 27, 1152-1165.

Hooghiemstra, H., 1984. Vegetational and climatic history of the high plain of Bogotá, Colombia: a continuous record of the last 3.5 million years. Dissertationas botanicae 79, J. Cramer, Vaduz, 368 pp.

Hooghiemstra, H. 1989. Quaternary and Upper Pliocene glaciations and forest development in the tropical Andes: Evidence from a long high-resolution pollen record from the sedimentary basin of Bogotá, Colombia. Palaeogeogr., Palaeoclimatol., Palaeoecol. 72, 11-26.

Hooghiemstra, H., Berrio, J.C., Groot, M.H.M., Bogotá-A., R.G., Moscol-Olivera, M., González-Carranza, Z., 2012. The dynamic history of the upper forest line ecotone in the northern Andes. In: Randall, 
R.W. (Ed.), Ecotones between forest and grassland. Springer-Science and Business Media, New York, 229-246.

Hooghiemstra, H., Ran, E.T.H., 1994. Late and Middle Pleistocene climatic change and forest development in Colombia: pollen record Funza II (2-158 m core interval). Palaeogeogr., Palaeoclimatol., Palaeoecol. 109, 211-246.

Islebe, G.A., H. Hooghiemstra and K. Van der Borg. 1995. A cooling event during the Younger Dryas Chron in Costa Rica. Palaeogeogr., Palaeoclimatol., Palaeoecol. 117, 73-80.

Jansen, J.H.F., Van der Gaast, S.J., Koster, B., Vaars A.J., 1998. CORTEX, a shipboard XRFscanner for element analyzes in split sediment cores. Marine Geology 151, 143-153.

Jaramillo, D., Parra, N., 1993. Aspectos biofísicos generales del Páramo de Frontino. Revista del ICNE 4(2), Colombia, 81-96.

Kuhry, P., 1988. Palaeobotanical-palaeoecological studies of tropical high Andean peatbog section (Cordillera Oriental, Colombia). Dissertationes Botanicae 116, J. Cramer, Berlin-Stuttgart, 241 pp..

Labat, D., 2005. Recent advances in wavelet analyzes: part 1. A review of concepts. J. of Hydrology 314 , 275-288.

Leyden, B.W., 2002. Pollen evidence for climatic variability and cultural disturbance in the Maya lowlands.

Lozano, G., Parra, L.N., Segecin, R., Ramirez, J.J., 1999. Inferencias paleolimnologicas del Holoceno basadas en diatomeas de la Laguna Puente Largo, Páramo de Frontino, Antioquia. In: Florez, M.T.,

Marchant, R.A., Behling, H., Berrio, J.C., Cleef, A., Duivenvoorden, J., van Geel, B, van der Hammen, T., Lozano, G. (Eds), Silicofossiles altoandinos. Ed. Gráficas Montoya, Medellin, Colombia, 57-116.

Marchant, R.A., Behling, H., Berrio, J.C., Cleef, A., Duivenvoorden, J., van Geel, B, van der Hammen, T., Hooghiemstra, H., Kuhry, P., Melief, B.M., van Reenen, G., Wille, M., 2001. Late Holocene Colombian vegetation dynamics. Quat. Sci. Rev. 20, 1289-1308.

Hooghiemstra, H., Kuhry, P., Melief, B.M., van Reenen, G., Wille, M., 2002. Colombian vegetation derived from pollen data at $0,3000,6000,9000,12,000,15,000$ and 18,000 radiocarbon year before present. J. Quat. Sci. 17, 113-129. 
1082

1083

1084

1085

1086

1087

1088

1089

1090

1091

1092

1093

1094

1095

1096

1097

1098

1099

1100

1101

1102

1103

1104

1105

1106

1107

1108

1109

1110

1111

Marchant, R.A., Berrío, J.C., Behling, H., Boom, A. Hooghiemstra, H., 2006. Colombian dry moist forest transitions in the Llanos Orientales - a comparison of model and pollen-based biome reconstructions. Palaeogeogr., Palaeoclimatol., Palaeoecol. 234(1), 28-44.

Marchitto, T.M., R. Muscheler, J.D. Ortiz, J.D. Carriquiry, Van Geen, A., 2010. Dynamical response of the tropical Pacific Ocean to solar forcing during the early Holocene. Science 330, 1378-1381.

Mayewski, P.A.,Rohling, E.E., Stager, J.C., Karlén, W., Maasch, K.A., Meeker, L.D., Meyerson, E.A., Gasse, F., van Krefeld, S., Holmgren, K., Lee-Thorp, J., Rosqvist, G., Rack, F., Staubwasser, M., Schneider, R.R., Steig, E.J., 2004. Holocene climate variability. Quat. Res. 62, 243-255.

Mommersteeg, H., 1998. Vegetation development and cyclic and abrupt climatic change during the late Quaternary. Ph.D. thesis, University of Amsterdam, Nehterlands, 212 pp.

Monsalve, C., 2015. Climatic change during the Late Glacial in the northwestern part of Colombia, based on palynology and microfluorescence-X. Ph.D. Thesis. Terre \& Environment 134, Earth and Environmental Science Section, University of Geneva, 149 pp. E-access: http://archiveouverte.unige.ch/unige:81059.

Moscol Olivera, M., Hooghiemstra, H. 2010. Three millennia upper forest line changes in northern Ecuador : pollen records and altitudinal vegetation distributions. Rev. Palaeobot. Palynol. 163, 113126.

Moy, C.M., Seltzer, G.O., Rodbell, D.T., Anderson, D.M. 2002. Variability of El Niño/Southern Oscillation activity at millennial timescales during the Holocene epoch. Nature 420, 162-165.

Muñoz, P., 2013. Holocene climate variability in tropical SA : case history from a high-mountain wet zone in NW Colombia based on palynology and X-ray microfluorescence. Ph. D. Thesis. Terre \& Environment 124, Earth and Environmental Science Section, University of Geneva, 178 pp. Eaccess: http://archive-ouverte.unige.ch/unige:34298.

Niemann, H., Haberzettl, T., Behling, H., 2009. Holocene climate variability and vegetation dynamics inferred from the (11700 cal yr BP) Laguna Rabadilla de Vaca sediment record, southeastern Ecuadorian Andes. The Holocene 19(2), 307-316.

Parra, L.N., 1991. Geología glacial del Páramo de Frontino. Universidad Nacional de Colombia, Medellín, 44 pp. (unpubl.).

Parra, L.N. 2005. Análisis facial de alta resolución de sedimentos del Holoceno Tardío en el Páramo de Frontino, Antioquia. Ph.D. Tesis. Instituto de Ciencias Naturales. Universidad Nacional de 
1113 Parra, L.N., Jaramillo, A., 1999. Análisis palinológico del núcleo Puente Largo Páramo de Frontino. Ed 1114 Gráficas Montoya. Medellín, 236 pp.

1115 Parra, L.N., Rangel, O., Van der Hammen, T., 2010a. Geomorfología del Páramo de Frontino. In : Rangel, 1116 J.O. (ed.), Colombia diversidad biótica 10, Instituto de Ciencias Naturales, Universidad Nacional de Colombia, Bogotá, 1-14.

1118 Parra, L.N., J.O. Rangel, Van der Hammen, T., 2010b. Modelo de facies para los humedales paramunos. In : Rangel, J.O. (ed.), Colombia diversidad biótica 10, Instituto de Ciencias Naturales, Universidad Nacional de Colombia, Bogotá, 15-41.

Parra, L.N., Rangel, J.O., Van der Hammen, T., 2010c. Los sedimentos paramunos y la estratigrafía de la turbera Llano Grande, Páramo de Frontino (Antioquia, Colombia). In: Rangel, J.O. (ed.), Colombia diversidad biótica 10, Instituto de Ciencias Naturales, Universidad Nacional de Colombia, Bogotá, 67-91.

Parra, L.N., Rangel, J.O., Van der Hammen, T., 2010d. Las tefras de los humedales del Páramo de Frontino (Antioquia, Colombia). In: Rangel, J.O. (ed.), Colombia diversidad biótica 10, Instituto de Ciencias Naturales, Universidad Nacional de Colombia, Bogotá, 93-100.

Petersen, L.C., Haug, G.H., 2006. Variability in the mean latitude of the Atlantic Intertropical Convergence Zone as recorded by riverine input of sediments to the Cariaco Basin (Venezuela). Palaeogeogr., Palaeoclimatol., Palaeoecol. 234, 97-113.

Petersen, L.C., Haug, G.H., Hughen, K.A., Röhl, U., 2000. Rapid changes in the hydrologic cycle of the tropical Atlantic during the last glacial. Science 290, 1947-1951.

Piperno, D.R., and J.G. Jones. 2003. Paleoecological and archaeological implications of a latePleistocene/Early Holocene record of vegetation and climate from the Pacific coastal plain of Panama. Quat. Res. 59, 79-87.

Poveda, G., A. Jaramillo., M.M. Gil., N. Quiceno., Mantilla, R., 2001. Seasonality in ENSO Related Precipitation, River Discharges, Soil Moisture, and Vegetation Index (NDVI) in Colombia. Water Resources Research 37, 2169-2178.

Poveda, G., Mesa,.O.J., 2000. On the existence of Lloró (the rainiest locality on Earth): Enhanced oceanatmosphere-land interaction by a low level jet. Geophys. Res. Lett. 27, 1675-1678. 
1141 Rangel, J.O., 1995. La diversidad florística en el espacio andino de Colombia. In: Churchill, S.P., 1142 Balslev, H., Forero, E. and Luteyn, J.L. (eds), Biodiversity and conservation of neotropical 1143 montane forests. Proceedings, New York Botanical Garden, 187-205.

1144 Rangel, J.O. (Ed), 2010. Colombia Diversidad Biótica X. Cambio global (natural) y climático (antrópico) en el páramo colombiano. Universidad Nacional de Colombia, Instituto de Ciencias Naturales, Bogotá, 556 pp.

Rangel, J.O., Aguilar, M., 1995. Una aproximación sobre la diversidad climática en las regiones naturales de Colombia. In: Rangel, J.O. (ed.), Colombia Diversidad Biótica 1, Editorial Guadalupe, Santafe de Bogotá.

Rangel, J.O., Lowy-C, P., Aguilar, M. (eds), 1997. Colombia: Diversidad Biótica II. Tipos de vegetación en Colombia. Instituto de Ciencias Naturales - IDEAM. Santafé de Bogotá, 436 pp.

Rangel, J.O., Sánchez, D., Ariza, C., 1999. Fitosociología del Páramo de Frontino. In : Tardiglacial y Holoceno del norte de la Cordillera Occidental de Colombia. Ed Gráficas Montoya. Medellín, p. 236.

Rangel , J.O., Van der Hammen, T., Jaramillo, R., 1982. Tipos de vegetación en el transecto Buritaca-La Cumbre Sierra Nevada de Santa Marta (entre 0 y 4100 m). Colombia Geográfica 10, 1-18.

Rasmusen, S.O., Andersen, K.K., Svensson, A.M., Steffensen, J.P., Vinther, B.M., Clausen, H.B., Siggaard-Andersen, M.L., Johnsen, S.J., Larsen, L.B., Dahl-Jensen, D., Bigler, M., Röthlisberger, R., Fischer, H., Goto-Azuma, A., Hansson, M.E., Ruth, U., 2006. A new Greenland ice core chronology for the last Glacial termination. J. Geophys. Res. 111, D06102, doi:10.1029/2005JD006079. .

Reimer, P., Baillie, M., Bard, E., Bayliss, A., Beck, J., Bertrand, C., Backwell, P., Buck, C., Burr, G., Cutler, K., Damon, P., Edwards, R., Fairbanks, R., Friedrich, M., Guilderson, T., Hogg, A., Hughen, K., Kromer, B., McCormac, G., Manning, S., Bronk Ramsey, C., Reimer, R., Remmele, S., Southon, J., Stuiver, M., Talamo, S., Taylor, F., Van der Plicht, J.,Weyhenmeyer. C., 2004. IntCal04 terrestrial radiocarbon age calibration, 0-26 cal kyr BP. Radiocarbon 46(3), 1029-1058.

Renssen, H., Seppä, H., Heiri, O., Roche, D.M., Goosse, H., Fichefet, T., 2009. The spatial and temporal complexity of the Holocene Thermal Maximum. Nature Geoscience 2, 411-414.

Renssen, H., Seppä, H., Crosta, X., Goosse, H., Roche, D.M., 2012. Global characterization of the Holocene Thermal Maximum. Quat. Sci. Rev. 48, 7-19. 
1170 Riedinger, M.A., Steinitz-Kannan, M., Last, W.M. Brenner, M., 2002. A 6100 14C yr record of El Niño 1171 activity from the Galapagos Islands. J. Palaeolimnol. 27, 1-7.

1172 Rodbell, D.T., Seltzer, G.O., Anderson, D.M., Abbott, M.B., Enfield, D.B., Newman, J.H., 1999. An 1173 15,000-year record of El Niño-driven alluviation in southwestern Ecuador. Science 283, 516-520.

1174 Röhl, U., Abrams, L.J., 2000. High-resolution, downhole and nondestructive core measurements from Sites 999 and 1001 in the Caribbean Sea: application to the Late Paleocene Thermal Maximum. Proc. Ocean Drill. Prog., Sci. Results 165, 191-203.

Rohling, E.J., Palike, H., 2005. Centennial-scale climate cooling with a sudden cold event around 8200 years ago. Nature 434, 975-979.

Roubik, D.W., Moreno, J.E., 1991. Pollen and spores of Barro Colorado Island. Monographs in Sytematic Botany 36, Missouri Botanical Garden. 268 pp.

Rull, V., Abbott, M.B., Polissar, P.J., Wolfe, A.P., Bezada, M., Bradley, R.S., 2005. 15'000-yr pollen record of vegetation change in high-altitude tropical Andes at Laguna Verde Alta, Venezuela. Quat. Res. 64,

1184 Ryan, P.D., Harper, D.A.T., Whalley, J.S., 1995. PALSTAT, Statistics for palaeontologists. Chapman and Hall (now Kluwer Academic Publishers), 31 pp.

Salomons, J.B., 1986. Paleoecology of volcanic soils in the Colombian Central Cordillera (Parque Nacional Natural de Los Nevados). Ph.D. thesis, University of Amsterdam, Netherlands. The Quaternary of Colombia 13.

Sánchez, D., 1998. Inventario florístico del páramo de Frontino (Urrao) Antioquia. Revista Facultad Nacional de Agronomía 51(2), 99-156.

Stansell, N.D., M.B. Abbott, V. Rull, D.T. Rodbell, M. Bezada, and E. Montoya. 2010. Abrupt Younger Dryas cooling in the northern tropics recorded in lake sediments from the Venezuelan Andes. Earth

1194 Stott, L., C. Poulsen, S. Lund, Thunell, R., 2002. Super ENSO and global climate oscillations at millennial time scales. Science 297, 222-226.

1196 Stuiver, M., Reimer, P.J., 1993. Extended 14C data base and revised CALIB 3.014 C age calibration program. Radiocarbon 2, 215-230.

1198 Talma, A.S. Vogel, J.C., 1993. A simplified approach to calibrating 14C dates. Radiocarbon 2, 317-322. 
1199 Thompson, L.G., 2000. Ice core evidence for climate change in the Tropics: implications for our future. Quat. Sci. Rev. 19, 19-35.

1201 Thompson LG., Mosley-Thompson, E., Davis, M.E., Lin, P.N., Henderson, K.A., Cole-Dai, J., Bolzan, J.F., Liu, K.B., 1995. Late Glacial stage and Holocene tropical ice core records from Huascarán, Peru. Science $269,46-50$.

Thompson LG., Mosley-Thompson, E., Henderson, K.A., 2000. Ice-core palaeoclimate records in tropical SA since the Last Glacial Maximum. J. Quat. Sci. 15 (4), 377-394.

Thouret, J.C., Cantagrel, J.M., Robin, C., Murcia, C., Salinas, R., Cepeda, H., 1995. Quaternary eruptive history and hazard-zone model at Nevado del Tolima and Cerro Machin volcanoes, Colombia. J. Volcanol. Geotherm. Res. 66, 397-426.

Thouret, J.C., Van der Hammen, T., Salomon, B., Juvigné, E., 1996. Paleoenvironmental changes and glacial stades of the last 50'000 years in the Cordillera Central, Colombia. Quat. Res. 46, 1-18.

Torrence, C., Compo G., 1998. A practical guide to Wavelet Analysis. Bull. Amer. Meteorol. Soc. 79(1), 6178.

Torres, V. 2005. Pliocene-Pleistocene evolution of flora, vegetation and climate: a palynological and sedimentological study of a $586 \mathrm{~m}$ core from the Bogotá Basin, Colombia. Ph D Thesis, Institute for Biodiversity and Ecosytems Dynamic (IBED), University of Amsterdam, 181 pp.

Torres, V., Hooghiemstra, H., Lourens, L., Tzedakis, P.C., 2013. Astronomical tuning of long pollen records

Urrego, D.H., Hooghiemstra, H., Rama-Corredor, O., Martrat, B., Grimalt, J.O., Thompson, L., Bush, M.B., vegetation changes in the tropical Andes using ecological grouping and ordination methods. Climate of the Past 12, 697-711.

Van Boxel, J.H., González-Carranza Z., Hooghiemstra, H., Bierkens, M., Vélez, M.I., 2014. Reconstructing past precipitation from lake levels and inverse modelling for Andean lake La Cocha. J. Palaeolimnol. $51,63-77$. 
1229 Van der Hammen, T., 1974. The Pleistocene change of vegetation and climate in tropical SA. Journal of Biogeography 1, 3-26.

1231 Van der Hammen, T., Barelds, J., De Jong, H., De Veer, A.A., 1980/1981. Glacial sequence and environmental history in the Sierra Nevada del Cocuy (Colombia). Palaeogeogr., Palaeoclimat., Palaeoecol. 32, 247-340.

Van der Hammen, T., González. E., 1960a. Holocene and Late Glacial climate and vegetation of páramo Palacio (Eastern Cordillera, Colombia, SA). Geologie en Mijnbouw. 39 (12), 737-746.

Van der Hammen, T., González, E., 1960b. Upper Pleistocene and Holocene climate vegetation of the "Sabana de Bogotá", (Colombia, SA). Leidse Geologische Mededelingen 25, 126-315.

Van der Hammen, T., González, E. 1963. Historia de clima y vegetación del Pleistoceno Superior y del Holoceno de la Sabana de Bogotá. Boletín Geológico (XI) 1-3, 189-266.

Van der Hammen, T., Hooghiemstra, H., 2003. Interglacial-glacial Fúquene-3 pollen record from Colombia: an Eemian to Holocene climate record. Global and Planetary Change 36, 181-199.

Van der Hammen, T., Hooghiemstra, H., 1995. The El Abra stadial, a Younger Dryas equivalent in Colombia. Quat. Sci. Rev. 14, 841-851.

Van der Hammen, T., Rangel, O., Cleef, A.M. (eds.) 2005. La Cordillera Occidental Colombiana transecto Tatamá. Studies on Colombian Ecosystems 6, Cramer-Borntraeger, Berlin-Stuttgart, 972 pp.

Van der Hammen, T., Werner, J.H., Van Dommelen, H., 1973. Palynological record of the Northern Andes: a study of the Pliocene and lower Quaternary of the Colombian Eastern Cordillera and the early evolution of its high-Andean biota. Rev. Palaeobot. Palynol. 16, 1-122.

Van Geel, B., Van der Hammen, T., 1973. Upper Quaternary vegetational and climatic sequence of the Fúquene area, Eastern Cordillera, Colombia. Palaeogeogr., Palaeoclimat., Palaeoecol. 14, 9-92.

Van 't Veer, R., Hooghiemstra, H., 2000. Montane forest evolution during the last $650000 \mathrm{yr}$ in Colombia: a multivariate approach based on pollen record Funza-I. J. Quat. Sci. 15, 329-346.

Van 't Veer, R., Islebe, G.A., Hooghiemstra, H., 2000. Climatic change during the younger Dryas chron in Northern SA: a test of the evidence. Quat. Sci. Rev. 19, 1821-1835.

Velásquez, C.A., 1999. Análisis palinológico del núcleo Llano Grande Páramo de Frontino. In : Tardiglacial y Holoceno del norte de la Cordillera Occidental de Colombia. Ed Gráficas Montoya, Medellín, 236 pp. 
1261 Velásquez, C.A., Hooghiemstra, H., 2013. Pollen-based 17-kyr forest dynamics and climate change from the Western Cordillera of Colombia; no-analogue associations and temporarily lost biomes. Rev. Paleobot. Palynol. 194, 38-49.

Velásquez, C.A., Parra, L.N., Sanchez, C., Rangel, J.O., Ariza, C.L., Jaramillo, A., 1999. Tardiglacial y Holoceno del norte de la Cordillera Occidental de Colombia. Ed. Gráficas Montoya, Medellin, Colombia, $236 \mathrm{pp}$.

Vélez, M.I., Hooghiemstra, H., Metcalfe, S., Wille, M., Berrío, J.C., 2006. Late Glacial and Holocene environmental and climatic changes from a limnological transeat through Colombia, Northern SA. Palaeogeogr., Palaeoclimat., Palaeoecol. 234, 81-96.

Vélez, M.I., Wille, M., Hoohiemstra, H., Metcalfe, S., Vandenberghe, J., Van der Borg, K., 2001. Late Holocene environment history of southern Chocó region, Pacific Colombia; sediment, diatom and pollen analysis of core El Caimito. Palaeogeogr., Palaeoclimat., Palaeoecol. 173, 197-214.

Vizy, E.K., Cook, K.H., 2007. Relationship between Amazon and high Andes rainfall. Journal of Geophysical Research 112, D07107.

Vuille, M., Garreaud, R.D., 2012. Ocean-atmosphere interactions on interannual to decadal timescales. In: Matthews, J.A., Bartlein, K.R., Briffa, A., Dawson, A., de Vernal, A., Denham, T., Fritz, S.C., Oldfield, F. (eds.), Handbook of Environmental Change, 1, Sage Publications, London, Los Angeles, New Delhi, Singapore, 471-496.

Wanner, H., Mercolli, L., Grosjean, M., Ritz, S.P., 2014. Holocene climate variability and change; a databased review. J. Geol. Soc. London, doi:10.1144/jgs2013-101. climatology. Hydrological Processes 16, 1247-1260. 
Weng, H., Lau, K.M., 1994: Wavelets, period doubling, and time-frequency localization with application to organization of convection over the tropical western Pacific. J. Atmos. Sci. 51, 2523-2541.

1291 Weng, C., Bush, M.B., Curtis, J.H., Kolata, A.L., Dillehay, T.D., Binford, M.W., 2006. Deglaciation and Holocene climate change in the western Peruvian Andes. Quat. Research 66, 87-96.

1293 Wille, M., Hooghiemstra, H., Behling, H., Van der Borg, K., Negret, A.J. 2001. Environmental change in the Colombian subandean forest belt from 8 pollen records: the last $50 \mathrm{kyr}$. Vegetation and Archaeobotany 10, 61-77.

Wille, M., Hooghiemstra, H., van Geel, B., Behling, H., de Jong, A., van der Borg, K., 2003. Submillenniumscale migrations of the rainforest-savanna boundary in Colombia: ${ }_{14} \mathrm{C}$ wigglematching and pollen analysis of core Las Margaritas. Palaeogeogr., Palaeoclimatol.,Palaeoecol. 193, 201-223.

1299 Yancheva, G., Nowaczyk, N.R., Mingram, J., Dulski, P., Schettler, G., Negendank, J.F.W., Liu, J., Sigman, D.M., Peterson, L.C., Haug, G.H., 2007. Influence of the intertropical convergence zone on the East Asian monsoon. Nature 445, 74-77.

Yi, H., Shu, H., 2012. The improvement of the Morlet wavelet for multi-period analysis of climate data. 


\section{List of figures and tables}

Fig. 1: Location map of the Páramo de Frontino at the northwestern termination of the Western Cordillera in Colombia and seasonal positions of the present-day Intertropical Convergence Zone (ITCZ). Locations numbered 1 to 8 show sites mentioned in the text: 1) marine Cariaco Basin, Venezuela (Haug et al.,

Fig. 2: The Llano Grande (LLG) mire in the Páramo de Frontino: 2001); 2) Laguna Los Anteojos, Venezuela (Stansell et al., 2010); 3) Lake Fúquene, Colombia (BogotáAngel et al., 2011); 4) Laguna La Cocha, Colombia (González-Carranza et al., 2012); 5) Laguna Rabadilla de Vaca, Ecuador (Niemann et al., 2009); 6) Laguna de Chochos, Peru (Bush et al., 2005); 7) Laguna La Compuesta, Peru (Weng et al., 2006); 8) Huascaran ice core, Peru (Thompson et al., 1995).

A) Location of mire: the páramo vegetation is brown-coloured, the Andean and high-Andean arboreal forest lies between the green and brown lines (document from Bing Maps-satellite, Terraserver 2011).

B) The ca. $20 \mathrm{~m}$ in diameter yellow circle shows the central part of the basin where cores LLG-2 to -9 are located (photograph C. Monsalve); core LLG-1 (studied by Velásquez and Hooghiemstra, 2013) lies outside of the main depocentre.

Fig. 3: A) Present-day altitudinal vegetation distribution in the Western Cordillera of Colombia showing

C) Depth map of the LLG Basin and location, depth and date of recovered cores.

1332 Fig. 4: Lithology and depositional environment of sediments in the LLG basin based on cores LLG-1 to -9: in this study palynological data come from core LLG-2 and X-ray microfluorescence ( $\mu \mathrm{XRF})$ data from the main vegetation zones (modified after Velásquez and Hooghiemstra 2013). The changing position of the upper forest line (UFL) is used as a proxy for temperature change (see text).

B) Present-day distribution of the aquatic vegetation used as a proxy for water level changes and inferred precipitation (after Parra et al. 2010b).

$$
\text { core LLG-5. This paper covers essentially palaeoenvironmental zone 3. Correlation lines labelled " } a \text {, }
$$
$b, c, d$ and $e$ " correspond to major lithological changes/markers; in the central part of the basin, 
where cores LLG-2 to -9 are located, they are considered as isochrons (used to calibrate the age model for LLG-2 data, see Suppl. Fig. 1).

Fig. 5: Age model for the LLG Basin. This model is based on $30 \mathrm{AMS}{ }^{14} \mathrm{C}$ datings (see Table 2) and is representative for the central part of the basin (Fig. 2C) where core LLG-5 is located (see text for explanation). This model has been used to convert $\mu$ XRF sample depth from core LLG-5 to age. See figure 4 for lithological legend. Lines labelled $a, b, c, d$ and e correspond to isochrons in the central part of the basin (Fig. 4). From surface down to time line $a$ (at a depth of about $4 \mathrm{~m}$ ), this model can

Fig. 6: Palynological (core LLG-2) and X-ray microfluorescence ( $\mu \mathrm{XRF}$, core LLG-5) results for the Holocene also be applied directly to the palynological data in core LLG-2. Isochrons $b, c$ and $d$ are not at the same depth in cores LLG-5 and LLG-2 and the model has been slightly adapted to convert palynological sample depth from core LLG-2 to age (see text and Suppl. Fig. 1 for explanation). and late Younger Dryas (YD). Records of upper forest line (UFL) and mean annual temperature (MAT, inferred from AP\% record), water depth (inferred from aquatic vegetation record) and of $\mathrm{Ti}$ and $\mathrm{Fe}$ ( $\mu$ XRF-based). The time series analysis using the Morlet wavelet spectrum shows frequencies for $\mathrm{Ti}$ (see text for explanation); it has been carried out over the last 12,000 years and uses the original $\mu \mathrm{XRF}$ data at sub-annual time scale; the moving average 14 pt has been used only for display purposes. At

Fig. 7: Palaeoennvironmental reconstruction in the Páramo de Frontino compared with other selected pollen and one ice core records in the northern and central Andes (see site location in figure 1). the right hand side a synthesis of environmental conditions. Comparison of proxy-derived temperature $(\mathrm{T})$ and humidity $(\mathrm{H})$ data.

Fig. 8. Comparison of temperature and precipitation data derived from several biotic and abiotic proxies in the Páramo de Frontino and the marine Cariaco Basin in Venezuela. Implications for regional climate mechanisms. Cariaco data are derived from Haug et al. (2001) for X-ray fluorescence and from Lea et al. (2003) for sea surface temperature (SST). 
1366 Table 1. Taxa recognized in the palynological study of the Páramo de Frontino. Taxa are grouped 1367 according to ecological (see figure $3 \mathrm{~A}$ ). Aquatic taxa are grouped according to their preference in relation to water depth (see figure 3B).

1369

1370 Table 2. Radiocarbon ages and bulk sample specific information (see figure 5 and Suppl. Fig. 1). 1371 


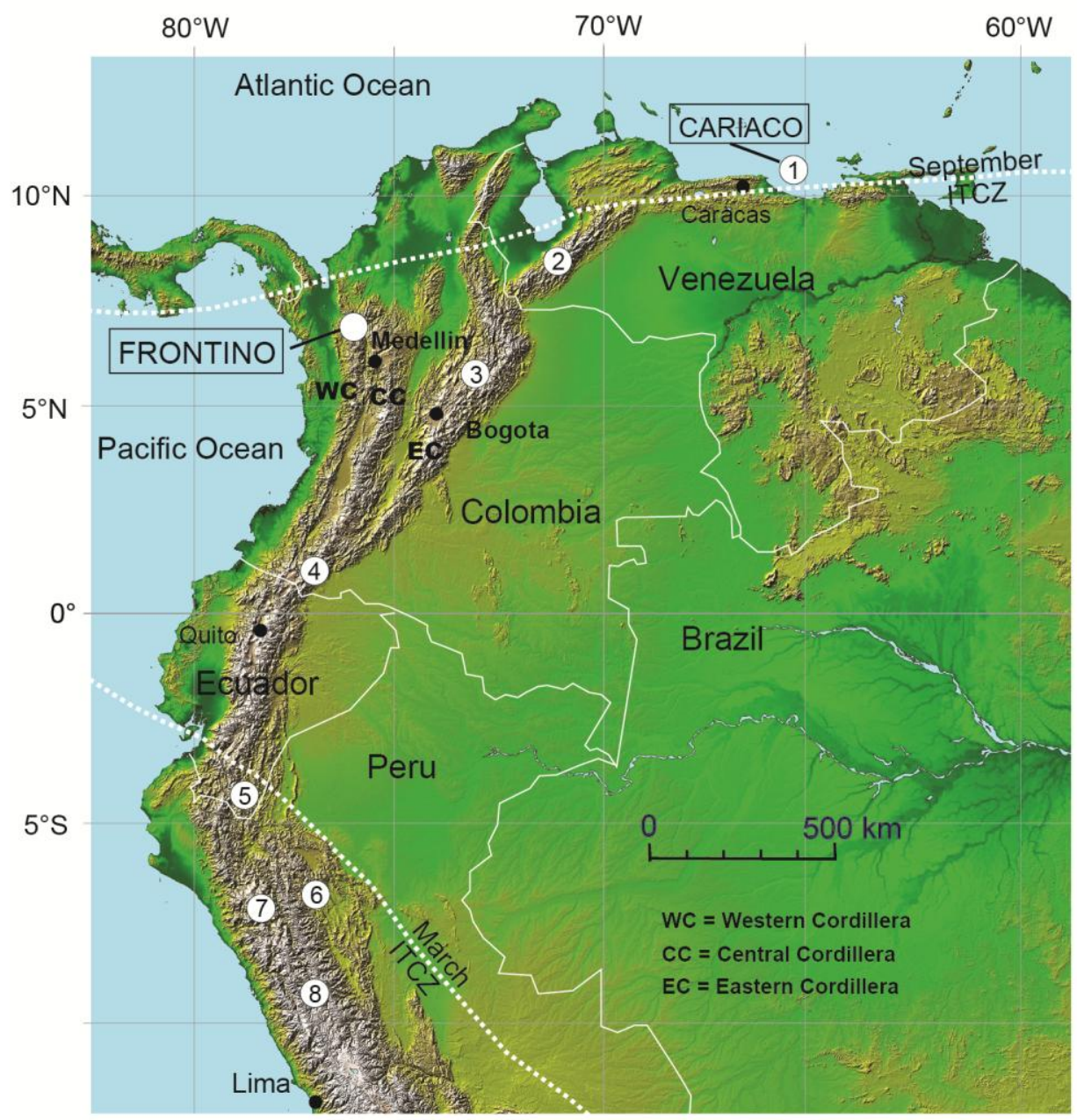

1372

1373 

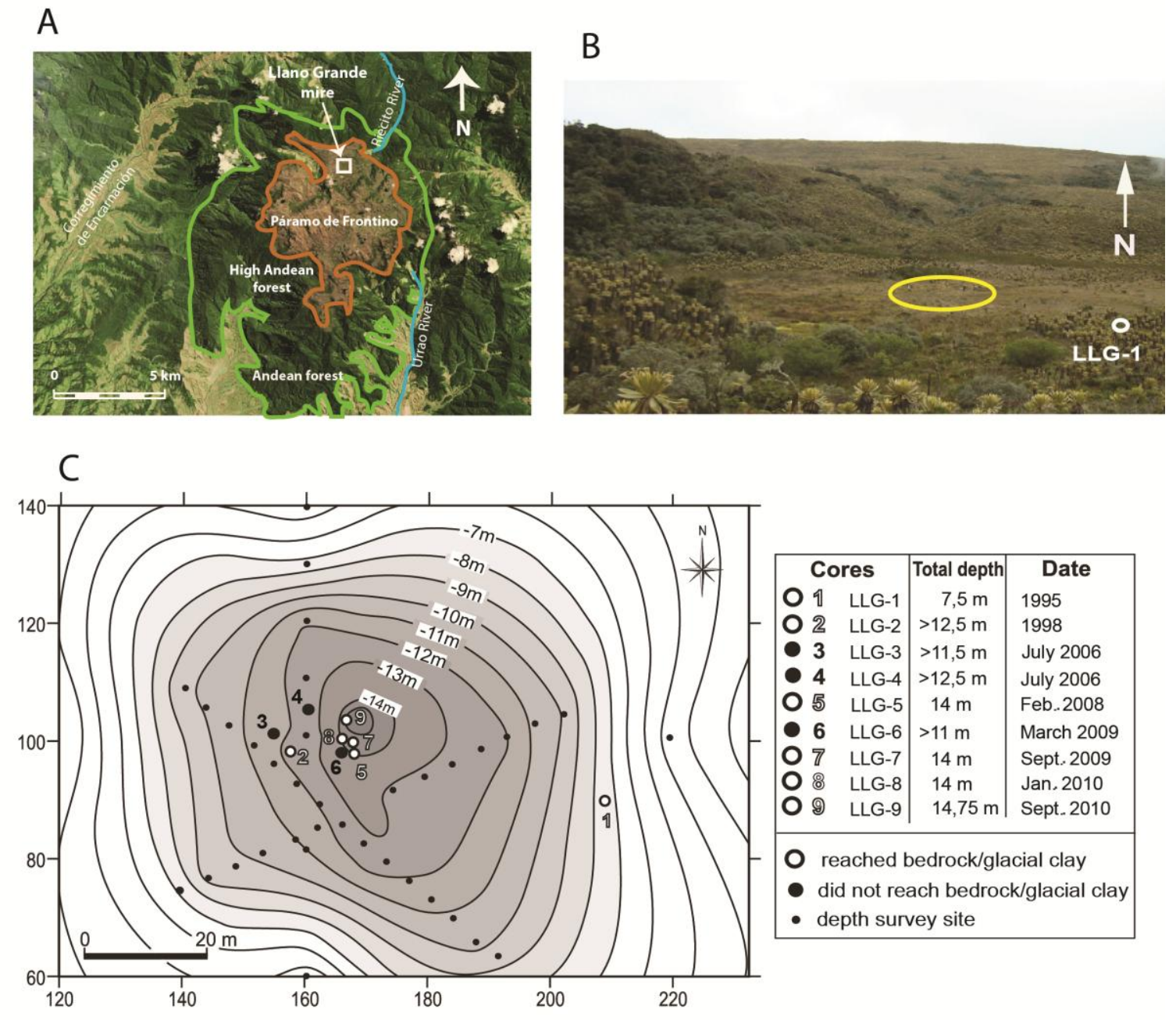
A

W

E

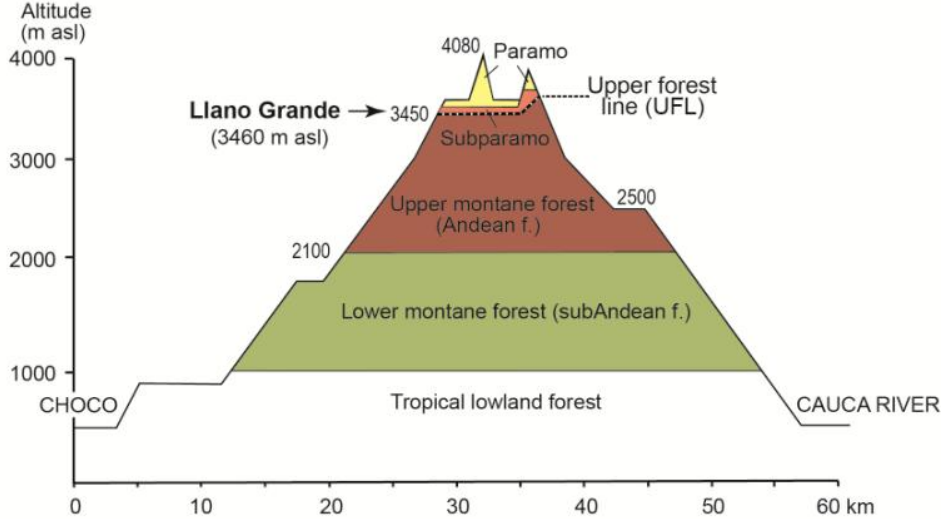

1376

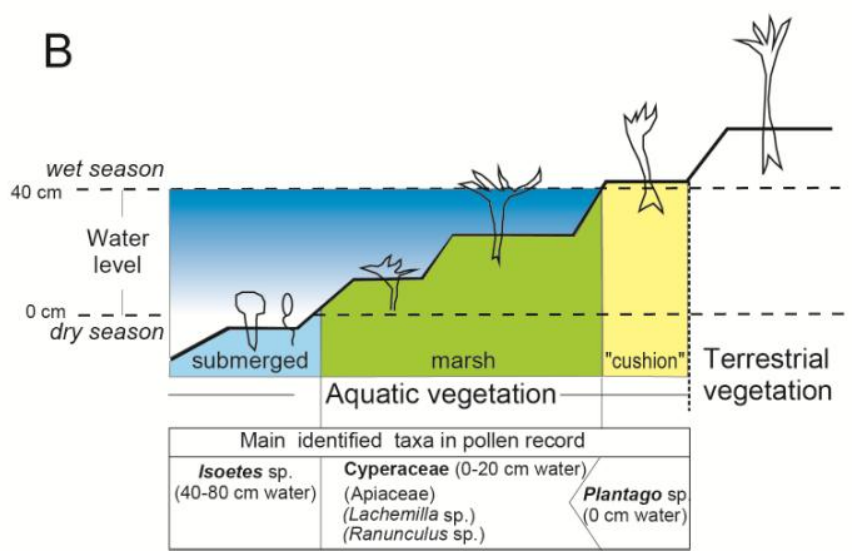

1377 


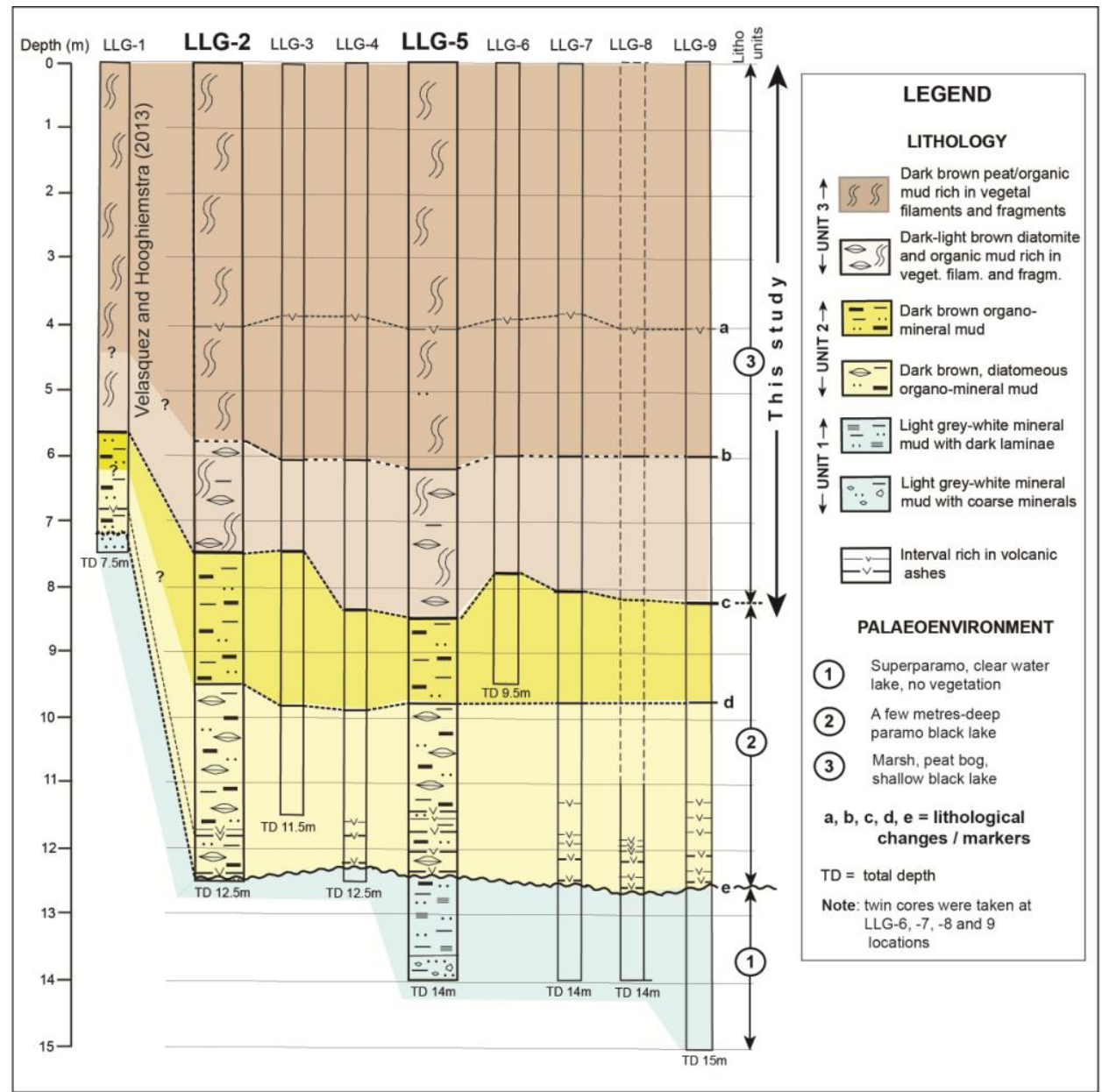




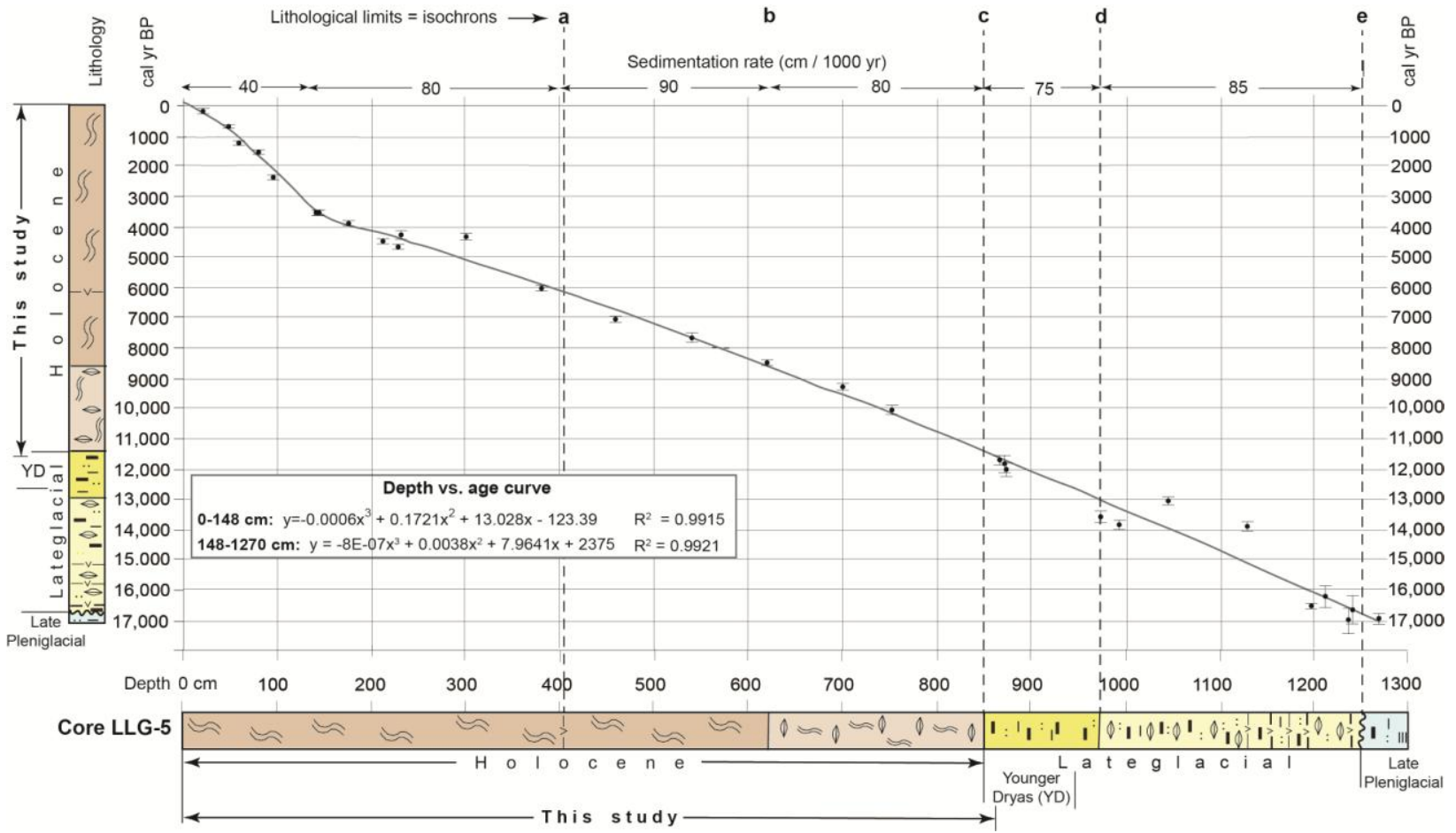




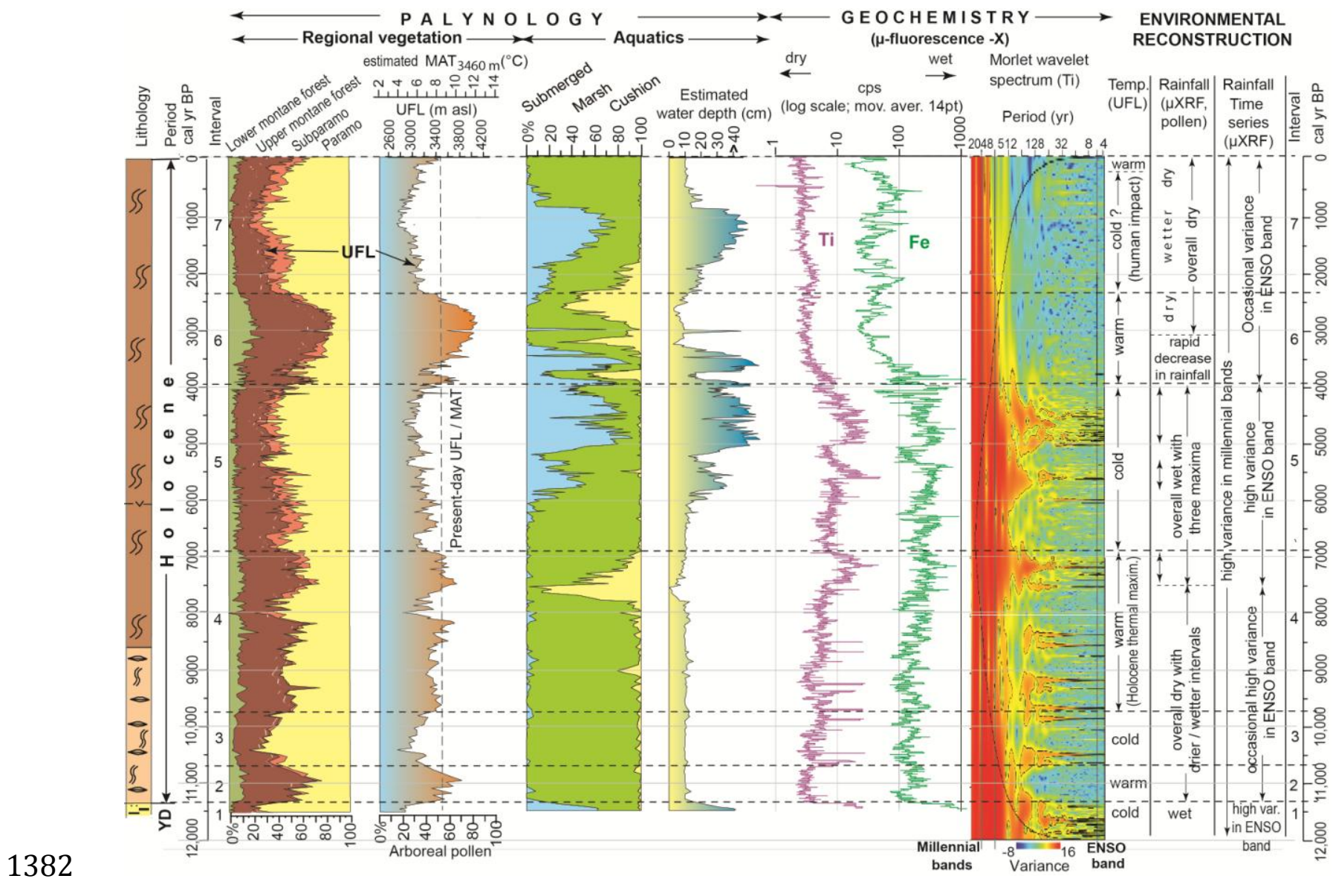




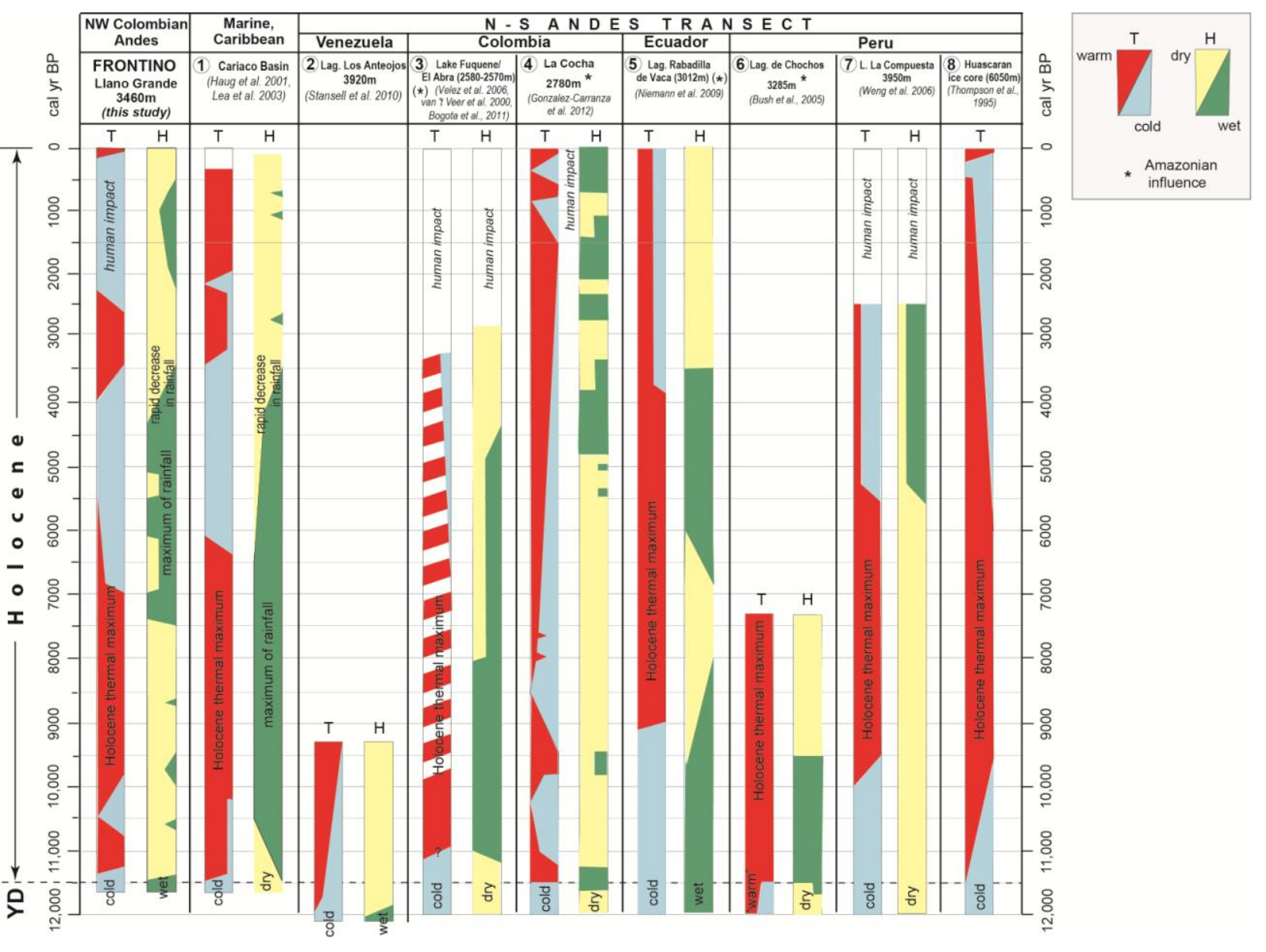

1384

1385 


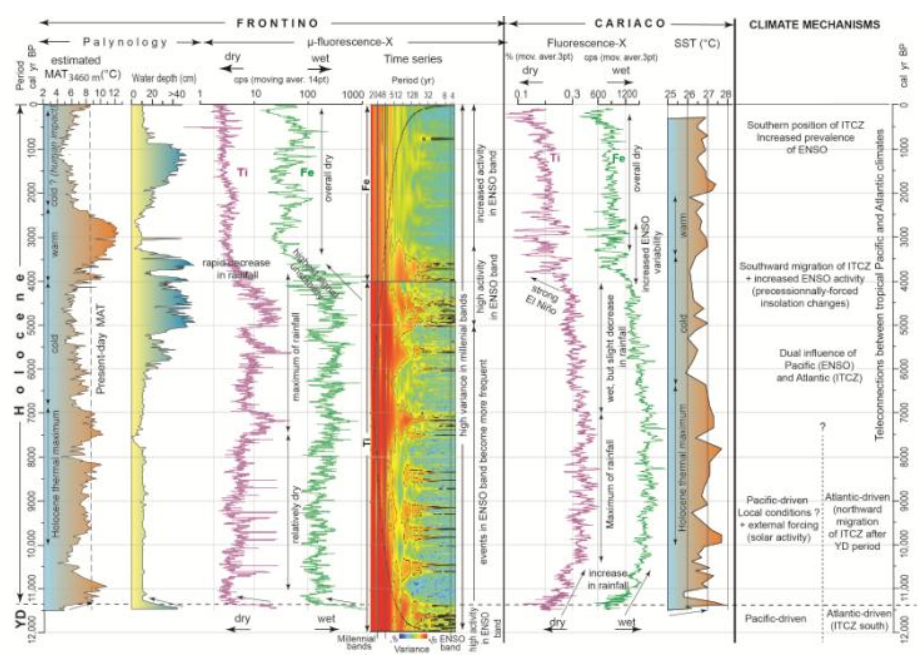




\begin{tabular}{|c|c|c|c|}
\hline \multicolumn{2}{|c|}{ REGIONAL VEGETATION } & \multicolumn{2}{|c|}{ LOCAL VEGETATION (AQUATICS) } \\
\hline Altitudinal range & Taxa & $\begin{array}{l}\text { Group } \\
\text { (water depth } \\
\text { range) }\end{array}$ & Taxa \\
\hline \multirow{2}{*}{$\begin{array}{l}\text { SubAndean (or } \\
\text { lower mountane } \\
\text { forest) } \\
(\sim 1000 \text { to } 2100 \mathrm{~m} \\
\text { asl) }\end{array}$} & \multirow{2}{*}{$\begin{array}{l}\text { Acalypha, Alcornea, Bignonaceae, } \\
\text { Cecropia, Fabaceae, Mimosaceae, } \\
\text { Pilea, Sapium , Urticales }\end{array}$} & $\begin{array}{c}\text { Submerged } \\
(40-80 \mathrm{~cm})\end{array}$ & Isoetes \\
\hline & & $\begin{array}{c}\text { Marsh } \\
(0-20 \mathrm{~cm})\end{array}$ & $\begin{array}{l}\text { Apiaceae, Cyperaceae, } \\
\text { Hydrocotyle, Lachemilla, } \\
\text { Ranunculus }\end{array}$ \\
\hline \multirow[b]{2}{*}{$\begin{array}{l}\text { Andean (or } \\
\text { upper montane } \\
\text { forest) } \\
\text { (2100 to } 3450 \mathrm{~m} \\
\text { asl) }\end{array}$} & \multirow{2}{*}{$\begin{array}{l}\text { Alnus, Araliaceae, Ardisia, } \\
\text { Bocconia, Clethra, Clusia, } \\
\text { Cyatheaceae, Drimys, Eugenia, } \\
\text { Gaiadendron, Hedyosmum, } \\
\text { Hesperomeles, Ilex, Juglans, } \\
\text { Melastomataceae, Miconia, } \\
\text { Mirica, Myrsine, Myrtaceae, Pinus, } \\
\text { Podocarpus, Prunus, Solanaceae, } \\
\text { Symplocos, Thalictrum, Vallea, } \\
\text { Viburnum, Weinmannia }\end{array}$} & $\begin{array}{c}\text { Cushion } \\
(0 \mathrm{~cm})\end{array}$ & Plantago \\
\hline & & & \\
\hline $\begin{array}{l}\text { Subpáramo } \\
\text { (3450 to } 3550 \mathrm{~m} \\
\text { asl) }\end{array}$ & Asteraceae, Ericaceae, Polylepis & & \\
\hline $\begin{array}{l}\text { Páramo } \\
\text { (3550 to } 4100 \mathrm{~m} \\
\text { asl) }\end{array}$ & $\begin{array}{l}\text { Aragoa, Arcytophyllum, Blechnum } \\
\text { Caryophyllaceae, Gentianaceae, } \\
\text { Geranium, Hypericum, Lamiaceae, } \\
\text { Lycopodiaceae, Poaceae, Rumex, } \\
\text { Sisyrincum, Valeriana }\end{array}$ & & \\
\hline
\end{tabular}




\begin{tabular}{|c|c|c|c|c|c|c|c|c|c|}
\hline Core & Interval (cm) & $\begin{array}{l}\text { Av. depth } \\
\text { (cm) }\end{array}$ & $\begin{array}{c}{ }^{14} \mathrm{C} \text { age } \\
\text { (yr BP) }\end{array}$ & $\begin{array}{c}\text { Deviation } \\
( \pm)\end{array}$ & $\begin{array}{c}\text { cal yr BP } \\
\text { (Intcal04) } \\
2 \sigma\end{array}$ & $\begin{array}{c}\text { Deviation } \\
( \pm)\end{array}$ & $\begin{array}{l}\delta^{13} \mathrm{C} \\
\text { (o/oo } \\
\text { PDB) }\end{array}$ & ${ }^{14} \mathrm{C}$ Lab & Dated material \\
\hline LLG-2 & $19-21$ & 20 & 130 & 30 & 170 & 110 & -25 & Poz-235 & peat \\
\hline LLG-5 & $50-53$ & 51.5 & 770 & 40 & 700 & 40 & -27.6 & Beta-259645 & fibrous organic mud \\
\hline LLG-2 & $58-61$ & 59.5 & 1280 & 30 & 1230 & 60 & -25 & Poz-236 & fibrous organic mud \\
\hline LLG-2 & $76-80$ & 78 & 1600 & 30 & 1480 & 70 & -25 & Poz-237 & peat \\
\hline LLG-2 & $94-98$ & 96 & 2370 & 35 & 2410 & 75 & -25 & Poz-238 & fibrous organic mud \\
\hline LLG-2 & $139-148$ & 143.5 & 3340 & 35 & 3560 & 85 & -25 & Poz-251 & fibrous organic mud \\
\hline LLG-5 & $140-142$ & 141 & 3330 & 40 & 3570 & 110 & -24.3 & Beta-259646 & fibrous organic mud \\
\hline LLG-2 & $175-178$ & 176.5 & 3630 & 35 & 3930 & 80 & -25 & Poz-232 & peat \\
\hline LLG-2 & $211-214$ & 212.5 & 4030 & 35 & 4490 & 70 & -25 & Poz-250 & fibrous organic mud \\
\hline LLG-2 & $228-230$ & 229 & 4120 & 40 & 4670 & 150 & -25 & Poz-239 & fibrous organic mud \\
\hline LLG-5 & $230-233$ & 231.5 & 3890 & 40 & 4290 & 130 & -25.7 & Beta-259647 & fibrous organic mud \\
\hline LLG-5 & $300-303$ & 301.5 & 3910 & 40 & 4335 & 95 & -26.2 & Beta-259648 & fibrous organic mud \\
\hline LLG-5 & $380-383$ & 381.5 & 5230 & 40 & 6045 & 125 & -24.7 & Beta-259649 & fibrous organic mud \\
\hline LLG-5 & $460-463$ & 461.5 & 6170 & 50 & 7090 & 150 & -25.6 & Bata-259650 & fibrous organic mud \\
\hline LLG-5 & $540-543$ & 541.5 & 6830 & 50 & 7665 & 85 & -25.3 & Beta-259651 & fibrous organic mud \\
\hline LLG-5 & $620-623$ & 621.5 & 7730 & 50 & 8505 & 95 & -26.3 & Beta-259652 & fibrous organic diatom. mud \\
\hline LLG-5 & $700-703$ & 701.5 & 8280 & 50 & 9280 & 160 & -25 & Beta-259653 & fibrous organic diatom. mud \\
\hline LLG-5 & $752-754$ & 753 & 8910 & 50 & 10045 & 155 & -26.1 & Beta-259336 & fibrous organic diatom. mud \\
\hline LLG-5 & $866-868$ & 867 & 10080 & 50 & 11685 & 295 & -24.8 & Beta-246337 & organo-mineral mud \\
\hline LLG-5 & $872-874$ & 873 & 10150 & 50 & 11830 & 220 & -25.6 & Beta-246338 & organo-mineral mud \\
\hline LLG-3 & $874-876$ & 875 & 10280 & 60 & 12030 & 215 & -29.1 & Poz-21086 & organo-mineral mud \\
\hline LLG-3 & $974-976$ & 975 & 11740 & 70 & 13590 & 170 & & Poz-21087 & organo-mineral mud \\
\hline LLG-3 & $994-996$ & 995 & 11980 & 70 & 13860 & 150 & & Poz-21088 & organo-mineral diatom. mud \\
\hline LLG-5 & $1046-1048$ & 1047 & 11120 & 60 & 13040 & 140 & -27 & Beta-246339 & organo-mineral diatom. mud \\
\hline LLG-8 & $1130-1134$ & 1132 & 11950 & 100 & 13905 & 105 & -26.6 & Beta-286835 & organo-mineral mud \\
\hline LLG-5 & $1197-1200$ & 1198.5 & 13850 & 70 & 16505 & 365 & -27 & Beta-259656 & organo-mineral mud \\
\hline LLG-4 & $1212-1214$ & 1213 & 13590 & 90 & 16190 & 430 & & Poz-21090 & organo-mineral mud \\
\hline LLG-4 & $1237-1239$ & 1238 & 14210 & 90 & 16970 & 460 & & Poz-21091 & organo-mineral mud \\
\hline LLG-8 & $1240-1243$ & 1241.5 & 13940 & 70 & 16610 & 180 & -28.9 & Beta-278833 & organo-mineral mud \\
\hline LLG-8 & $1266-1274$ & 1270 & 14170 & 70 & 16910 & 175 & -27.8 & Beta-278834 & organo-mineral mud \\
\hline
\end{tabular}

